\title{
Symposium review: Structure-function relationships in cheese ${ }^{1}$
}

\author{
Prabin Lamichhane, ${ }^{*} \dagger$ Alan L. Kelly,† and Jeremiah J. Sheehan*2 \\ ${ }^{*}$ Teagasc Food Research Centre, Moorepark, Fermoy, Co. Cork, Ireland P61 C996 \\ †School of Food and Nutritional Sciences, University College Cork, Cork, Ireland T12 YN60
}

\begin{abstract}
The quality and commercial value of cheese are primarily determined by its physico-chemical properties (e.g., melt, stretch, flow, and color), specific sensory attributes (e.g., flavor, texture, and mouthfeel), usage characteristics (e.g., convenience), and nutritional properties (e.g., nutrient profile, bioavailability, and digestibility). Many of these functionalities are determined by cheese structure, requiring an appropriate understanding of the relationships between structure and functionality to design bespoke functionalities. This review provides an overview of a broad range of functional properties of cheese and how they are influenced by the structural organization of cheese components and their interactions, as well as how they are influenced by environmental factors (e.g., $\mathrm{pH}$ and temperature).
\end{abstract}

Key words: cheese, structure, function, interaction

\section{INTRODUCTION}

Overall, the global consumption of cheese is increasing continuously and is projected to increase by $\sim 13.5 \%$ between 2016 and 2025 (OECD/FAO, 2016). Simultaneously, consumers/end-users have increasingly been demanding enhanced physico-chemical properties, sensory and nutritional quality, and optimal usage characteristics of cheese, all at a reasonable cost. This is primarily driven by factors such as growing consumer awareness of the role of diet in health and well-being, the potential to use structure to influence flavor release and sensory experience, and the extensive use of cheese as an ingredient in food retail applications. Such expanding consumer demands have triggered the focus of food researchers and cheese producers toward the improvement in the quality of existing products or the design of new innovative products.

\footnotetext{
Received June 22, 2017.

Accepted August 15, 2017.

${ }^{1}$ Presented as part of the Teagasc-Moorepark/University College Cork Cheese Symposium at the ADSA Annual Meeting, Pittsburgh, Pennsylvania, June 2017.

${ }^{2}$ Corresponding author: Diarmuid.Sheehan@teagasc.ie
}

It is now well recognized that many of the desirable properties of cheese are largely determined by its structure. For example, structure plays an important role in determining the mechanical, rheological, and cooking properties of heated and unheated cheese (Lucey et al., 2003; Guinee, 2016), eye formation in several types of hard (e.g., Swiss type or Emmental) and semi-hard (e.g., Maasdam type) cheese (Daly et al., 2010), and texture perception (Rogers et al., 2009). More recently, it has also been reported that food structure plays a key role in flavor release (Taylor, 2002) and in the digestion and the absorption of nutrients (Parada and Aguilera, 2007; Singh et al., 2015). Apart from containing basic nutrients, the nutritional value of food can also be enhanced by introducing health-promoting and bioactive compounds, such as polyphenols and peptides. In this context, the cheese matrix can potentially be used as a delivery vehicle for bioactives and probiotics (Sharp et al., 2008; Rashidinejad et al., 2016). Thus, a better understanding of the complex interrelationship between structure and functionality (i.e., the so-called structurefunction relationship) is necessary to design of cheese types with specific functionalities. However, the full extent of the relationships between structure and functionality of cheese is not fully understood. The aim of this review is to provide an appropriate knowledge of how cheese structure may be manipulated to control and predict the functional properties of cheese.

\section{CHEESE COMPONENTS AND STRUCTURE}

Caseins, the main structural component of cheese, are present in the form of a network in the cheese matrix in which fat globules, water, minerals, bacteria, and dissolved solutes such as lactose, lactic acid, soluble salts, and peptides are all interspersed. The spatial arrangements of these components and their interactions determines the structure of cheese, which is influenced by relative volume fractions of each component and their properties (e.g., residual charge on the casein, composition of membrane materials of fat globules, and state of minerals, water, and fat), cheese manufacturing procedures, maturation conditions, and environmental 
conditions (e.g., pH, temperature, and solvent quality/ ionic strength), among other factors.

Like other food types, cheese encompasses a hierarchical structure, with scales that span from the molecular to the macroscale (Figure 1). At a macroscopic level, cheese is the assembly of curd particles (resulting from cutting of the gel in the case of brine-salted cheeses), or curd chips or pieces (resulting from milling of curds and dry salting, such as in Cheddar and Stilton cheese manufacture; Guinee, 2016). Eyes, slits/cracks, visible crystals, and mechanical openness are also macrostructural features of cheese. At the microscopic level, cheese is composed of microstructural components, such as the casein network, fat globules, and water droplets. At further higher levels of magnification (nano or molecular scale), microstructural components of cheese are formed from molecules and atoms. Structures at the macro, micro, nano, and molecular levels of organization all have an important role in various properties of cheese. Various techniques to study cheese structure, such as microscopy, rheology, magnetic resonance, and dynamic light scattering, have been reviewed extensively (e.g., Everett and Auty, 2008; El-Bakry and Sheehan, 2014).

From a materials science perspective, cheese can be viewed as a 2-phase composite material (also called "filled gels" or "gelled emulsions") containing fat globules as a filler in a protein gel matrix (Barden et al., 2015). Several researchers used this approach to study the role of milk fat and protein network on the mechanical and rheological properties of cheese (Rogers et al., 2010; Barden et al., 2015; Thionnet et al., 2017).

\section{MOLECULAR INTERACTIONS WITHIN THE CHEESE MATRIX}

Various molecular forces and interactions that act between the cheese components are considered important as they can influence the functionality of cheese. For example, it is suggested that the localized balance of the attractive and repulsive forces between casein controls the melting of heated cheese (Lucey et al., 2003). Moreover, the nature and extent of interactions of flavor compounds and nutrients with the food matrix can influence their release patterns in the mouth during mastication and in the gut during digestion, and this can in turn affect the sensorial and nutritional properties of food (Parada and Aguilera, 2007; Gierczynski et al., 2011). For such reasons, knowledge of molecular interactions and forces that act between cheese components is vital.

Some studies have characterized the interactive forces in milk gels and cheese curd using different dissociating agents such as urea, SDS, and EDTA (Lefebvre-Cases et al., 1998; Gagnaire et al., 2002; Zamora et al., 2012). These dissociating agents are known to disrupt specific types of bond or interaction; for example, hydrophobic interactions and hydrogen bonds can be disrupted by SDS or urea, respectively, whereas ionic bonds involving calcium salts are broken by the chelating effects of EDTA (Zamora et al., 2012). Lefebvre-Cases et al. (1998) characterized the interactive forces in rennetand acid-induced milk gels using different dissociating agents, and the results of their study suggested that hydrophobic interactions and calcium bonds were the most important forces for the stabilization of the structure of rennet milk gels. The contribution of hydrogen bonds seemed comparatively less important for the stability of rennet gel structure than the aforementioned forces. In acid-induced milk gels, hydrophobic and electrostatic interactions and hydrogen bonds have been shown to be important forces, whereas the contribution of calcium bonds have been found to be less important, most probably due to solubilization of colloidal calcium at low pH (Lefebvre-Cases et al., 1998). Calcium bonding, electrostatic interactions, and hydrogen bonds (to a lesser degree) contribute to the formation and stability of the para-casein matrix (after pressing) in Emmental cheese (Gagnaire et al., 2002). The major interaction

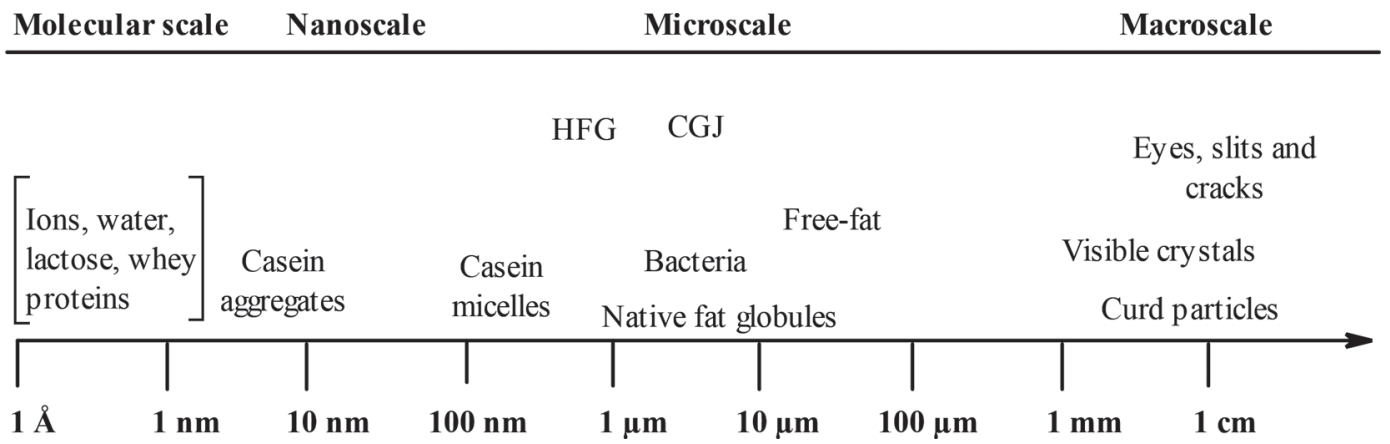

Figure 1. Characteristic length scales in cheese. HFG = homogenized fat globules, CGJ = curd granule junction. 
forces responsible for the structural organization of cheese components are defined as follows.

\section{Electrostatic Interactions}

Electrostatic interactions are important for food components that have a permanent electrical charge, such as dipoles or ions (McClements et al., 2009). Cheese is a complex system, and many components present in the cheese matrix are known to have electrical charge. For example, casein contains several AA residues with ionizable groups along their polypeptide chains, including phosphoseryl residues (Horne, 1998).

Electrostatic interactions between charged species are sensitive to the surrounding environment, particularly $\mathrm{pH}$ and ionic strength. The electrical charge of ionizable groups of food components depends on their $\mathrm{pKa}$ values relative to the $\mathrm{pH}$ of the surrounding aqueous solution (McClements et al., 2009). The aqueous phase of the cheese matrix contains several monovalent (e.g., $\mathrm{Na}^{+}$) and multivalent ions (e.g., $\mathrm{Ca}^{2+}$ ), and their level determines the ionic strength of the aqueous phase of the cheese matrix. The magnitude and range of the electrostatic repulsion between the casein in the cheese matrix may decrease with increasing ionic strength of the surrounding aqueous solution due to electrostatic screening effects (McClements et al., 2009).

Calcium-sensitive casein can cross-link with free calcium ions via calcium bridging, which is a type of electrostatic interaction (Dalgleish, 1983). Such interactions are considered important for the aggregation of renneted casein micelles during coagulation of milk (Dalgleish and Corredig, 2012). The binding of calcium by casein is suggested to decrease with increasing ionic strength and with decreasing temperature $\left(<40^{\circ} \mathrm{C}\right.$; Horne and Lucey, 2014).

\section{Hydrophobic Interactions}

Hydrophobic interactions are strong attractive forces between hydrophobic side groups of molecules in aqueous solution. The molecular origin of hydrophobic interactions is the fact that water molecules can form relatively strong hydrogen bonds with other water molecules, but not with nonpolar groups (McClements et al., 2009). Caseins have a significant fraction of nonpolar regions along their polypeptide chain (Horne, 1998). Thus, it is expected that the hydrophobic interactions may play an important role in determining the casein interactions in the cheese matrix (Lucey et al., 2003). The strength of hydrophobic interaction tends to increase with increasing temperature (McClements et al., 2009). Thus, it is believed that these interactions may make a significant contribution to the functionality of heated cheese (Lucey et al., 2003).

\section{Hydrogen Bonding}

Hydrogen bonds are simply an interaction between an electronegative atom (e.g., $\mathrm{O}, \mathrm{N}, \mathrm{F}$, and $\mathrm{Cl}$ ) and a hydrogen atom covalently bound to similar electronegative atoms. This is the one type of electrostatic force that tends to decrease in strength as the temperature increases (McClements et al., 2009). Hydrogen bonding is known to play a major role in hydration of proteins (Petukhov et al., 2004). Protein, including casein, contains several groups, such as carbonyl, amine, amide, and hydroxyl, which are able to interact with water through hydrogen bonding. Hydration of casein is considered important for the development of desirable texture and cooking properties of some cheese types, such as Mozzarella (Guo et al., 1997). Moreover, several studies have also suggested that the texture and cooking properties of low-fat cheeses can partially be improved by increasing the water-binding capacity of the protein matrix through approaches, such as modulation of $\mathrm{pH}$, and varying the level of colloidal calcium phosphate $(\mathbf{C C P})$ and sodium chloride $(\mathrm{NaCl})$ of the cheese matrix (Paulson et al., 1998; Sheehan and Guinee, 2004; McMahon et al., 2005; Johnson et al., 2009).

\section{Disulfide Bonding}

Disulfide bonds are a covalent bond formed between 2 thiol groups. This bond is considered important for cheese made from high heat-treated milk (e.g., queso blanco). High heat treatment of cheese milk unfolds heat sensitive whey proteins, exposing thiol groups that can form disulfide links with other reactive thiol groups of whey protein and casein through classical thiol-disulfide exchange reactions (Kethireddipalli and Hill, 2015). This type of reaction is influenced by redox potential (Poole, 2015), although little is published on this with regard to cheese matrices.

\section{FUNCTIONAL PROPERTIES OF CHEESE}

\section{Key Properties for Use as an Ingredient}

Cheese is extensively used as an ingredient in many foods. Two main functional requirements of cheese when used as an ingredient are (1) machinability (the ability of cheese to be shredded/diced/cut/sliced), and (2) specific cooking and melting properties (Lucey, 2008). Functional requirements of cheese largely depend on end-use application. For example, when cheese 
is used a topping on pizzas and lasagna, it needs to melt and stretch in a specific manner, whereas melting is undesirable when visual identity and shape of cheese on cooking is required, such as for queso blanco and paneer, although a certain degree of softening is desirable (Guinee, 2016). The various functional properties required when cheese is used as ingredients have been discussed extensively (Lucey, 2008; Guinee, 2016).

\section{Texture Perception}

Texture is an important factor determining the quality and identity of food, including cheese (Lawrence et al., 1987; Foegeding and Drake, 2007). For cheese, the main evaluation of texture occurs in the mouth (during mastication). However, in some eye-forming cheese types, such as Emmental and Maasdam, visual properties are also important. Proper eye development, encompassing number, size, shape, luster, and distribution, is an important textural property in those cheese types (Lucey et al., 2003; Daly et al., 2010).

During consumption, food is subjected to a complex series of oral manipulations, including ingestion, size reduction, and mixing with saliva, to form a bolus for safe swallowing, collectively termed as oral processing (Foegeding et al., 2010). Behavior of food during oral processing, such as breakdown patterns and extent of interaction (coating) with the oral surfaces, is thought to play an important role in the texture perception, and the structure and chemical composition of food can influence their behavior during oral manipulation (van Vliet et al., 2009; Foegeding et al., 2010). For example, the desirable texture of full-fat Cheddar cheeses compared with low-fat cheeses is considered to be partly due to role of fat in the desirable breakdown patterns of cheese during oral manipulation (Rogers et al., 2009; Foegeding et al., 2010). Similarly, the desirable texture of aged cheese is attributed to the age-related structural changes in the protein matrix, resulting in specific breakdown pattern during chewing (Rogers et al., 2009). Moreover, several studies of emulsion gels have reported that the properties of emulsion droplets, extent of droplet-matrix interactions, distribution of emulsion droplets, and characteristics of the gel matrix can all influence texture perception (Sala et al., 2007; Liu et al., 2015; Oliver et al., 2015). Thus, a fundamental knowledge of how the structure of cheese influences a specific textural response could be useful for designing cheese with desired texture profiles.

\section{Flavor Release and Perception}

Like texture, flavor (comprising taste and aroma) is also an important attribute of cheese. The heteroge- neous mixture of several hundred volatile and nonvolatile flavor compounds in cheese are the result of complex biochemical reactions during maturation, such as proteolysis, lipolysis, and glycolysis (McSweeney, 2004). During consumption, flavor compounds are released from the food matrix and diluted with saliva, which need to be transported to the flavor receptors in the mouth and nose for flavor perception to occur (Taylor, 2002). The correct balance and concentration of a wide range of flavor compounds, their release profile during oral processing, and the concentration and the rate at which those flavor compounds reach the receptors can all influence overall flavor perception (Taylor, 2002).

Food structure appears to play a key role on release of flavor compounds. Several studies on pure gels (e.g., protein gels, carrageenan gels), mixed gels (e.g., whey protein-polysaccharides), emulsion-filled gels (where emulsion droplets are embedded within a gel matrix), or solid lipoproteic colloid foods have shown that the gel structure affects volatiles and tastant release profile (Stieger and van de Velde, 2013; Kuo and Lee, 2014); in general, weaker gel textures and more porous structures gave higher flavor compound release during mastication. For example, Kuo and Lee (2014) reported that the rate of sodium release increased with increasing porosity and pore size of solid lipoproteic colloid foods. Proteolysis weakens the structure of protein network due to breakdown of the protein network; thus, it may be assumed that proteolysis facilitates the release of sapid compounds during mastication (Sousa et al., 2001).

Other factors, such as properties of the flavor compounds (e.g., volatility, solubility, and affinity toward the food matrix), and the subject's oral processing behavior (e.g., chewing, saliva flow rate, and air flow rate through the mouth and nose), can also influence the release of flavor compounds from the food matrix during oral manipulation (Taylor, 2002; Gierczynski et al., 2011). In addition, it is now well accepted that overall flavor perception can also be influenced by perceptual interactions between various sensory modalities (e.g., aroma, taste, and texture). For example, Visschers et al. (2006) reported that the intensity of aroma perceived by subjects decreased with increasing firmness of the food. In another study, the odor of Comté cheese enhanced the perception of saltiness in model cheeses (Lawrence et al., 2011).

Based on the above considerations, it is clear that the flavor profile of food/cheese can potentially be enhanced by modifying food structure. This approach could be manipulated to facilitate reduction of sodium and saturated fat without significantly altering flavor attributes or to ameliorate flavor defects in reduced-fat and reduced-salt cheeses. Such approaches merit further research. 


\section{Nutritional Properties}

Cheese, a nutrient-dense dairy product, is a good sources of proteins, vitamins, and minerals, particularly calcium, and phosphorus. However, the traditional method for evaluation of the nutritional quality of food (i.e., based on its composition) has recently been criticized because the method often neglects the effect of food matrix (structure) on nutrient release and absorption (Parada and Aguilera, 2007; Singh et al., 2015). For example, in an in vivo study using 6 mini-pigs, Barbé et al. (2013) reported that a renneted-gel matrix slowed down the rate of digestion of protein and absorption of AA as compared with liquid milk, probably due to lesser accessibility for digestive enzymes. In another study, Lamothe et al. (2012) studied the digestion pattern of Cheddar and Mozzarella cheese using an in vitro stomach model. The results of their study suggested that the degradation of protein and the kinetics of fatty acid release are closely associated with the physical characteristics of the cheese matrix; cheeses that exhibited greater cohesiveness and elasticity were more slowly degraded during digestion and gave slower rates of fatty acid release. More recently, some studies have reported that calcium in cheese can influence the free fatty acid bioaccessibility by producing insoluble calcium soaps with long-chain fatty acids at intestinal pH conditions (Ayala-Bribiesca et al., 2017). A better understanding of the role of cheese structure on digestion and absorption of nutrients within the gastrointestinal environment is key to designing cheese with enhanced nutritional quality. This area was reviewed in detail recently by Singh et al. (2015).

\section{Delivery of Bioactives and Probiotics}

Several studies have reported the potential for using the cheese matrix as a delivery vehicle for bioactives, such as vitamins (Madziva et al., 2006), minerals, and polyphenols (Rashidinejad et al., 2016). For example, Rashidinejad et al. (2016) successfully used full-fat hard cheese as a delivery vehicle for liposomal nanoencapsulated green tea catechins. Moreover, the cheese matrix can also serve as a vehicle for probiotic delivery (Sharp et al., 2008). High buffering capacity and the dense protein network of cheese are thought to protect probiotic bacteria against the harsh acid environment in the stomach (Gomes da Cruz et al., 2009), making cheese a potentially suitable carrier for probiotics.

However, it should be noted that many bioactives have an undesirable taste and odor, such as metallic taste of mineral salts, bitter taste of peptides, and fishy taste and odor of marine oils rich in n-3 fatty acids (Augustin and Sanguansri, 2008), which can alter the sensory properties of cheese. Moreover, the metabolites from high numbers of viable and metabolically active bacterial cells can also alter the sensory attributes of cheese. Therefore, these details need consideration when using cheese as a delivery vehicle for bioactive compounds and probiotics.

\section{ROLE OF STRUCTURAL ELEMENTS AND THEIR INTERACTIONS ON FUNCTIONAL PROPERTIES OF CHEESE}

The composition and the structural organization of cheese determine its functionality. In this section, we therefore focus on how the properties and the structural organization of the different phases of cheese, and the interactions between them influence cheese functionality. For the sake of simplicity, we have divided cheese structure into 4 phases: (1) protein phase, (2) fat phase, (3) aqueous phase, and (4) gas phase, particularly carbon dioxide $\left(\mathrm{CO}_{2}\right)$.

\section{Protein Phase}

Formation and Rearrangement of Protein Network. Formation of a protein network is a crucial step in cheese manufacture. The destabilization of casein micelles is one of the first steps in the manufacture of cheese. The mechanisms of destabilization of casein micelles by different means have been discussed extensively elsewhere (Dalgleish and Corredig, 2012). The destabilized casein micelles aggregate into chain and clusters, leading to formation of a 3-dimensional gel.

Several studies have reported that the factors, such as concentration of casein (Karlsson et al., 2007), properties of casein micelle (e.g., casein micelle size; Logan et al., 2014), and coagulation conditions (e.g., $\mathrm{pH}$, temperature, and rennet concentration; Wium et al., 2003; Ong et al., 2011a, 2012), can all influence the coagulation process. This may influence the arrangement of casein into protein matrix and also the microstructure and the quality of the final cheese. For example, milk renneted at lower $\mathrm{pH}(\mathrm{pH}$ 6.1) gave gels with more compact protein network than in gels renneted at higher $\mathrm{pH}(\mathrm{pH}>6.3$; Ong et al., 2012). Moreover, the texture of resulted Cheddar cheese was different; that is, cheese made using milk renneted at lower $\mathrm{pH}$ ( $\mathrm{pH}$ 6.1) had lower chewiness, gumminess, cohesiveness, and springiness than cheese made using milk renneted at higher $\mathrm{pH}(\mathrm{pH} 6.7$ or 6.5). Increased solubilization of CCP, accelerated rennet activity, and reduced charge repulsion between micelles at a lower milk $\mathrm{pH}$ are most likely to alter the rate and extent of aggregation, possibly leading to different microstructures of gels and cheese curds (Ong et al., 2012). In 
other studies, the coarseness of the protein network of the gel or cheese increased with increasing coagulation temperature (Wium et al., 2003; Ong et al., 2011a). This is probably due to enhancement of the protein network rearrangement and increasing strength of hydrophobic interactions at higher coagulation temperatures. Moreover, the calcium-binding by para-casein is suggested to increase with increasing temperature within the normal milk-coagulation temperature regimen, which may influence the aggregation kinetics of fully renneted casein micelles (Dalgleish, 1983; Horne and Lucey, 2014). This suggests that the functionality of the final cheese can be modified by optimization or modulation of initial cheese-making conditions. Thus, the influence of initial cheese-making conditions on the final properties of cheese should not be underestimated.

Rennet-induced gels are inherently unstable and likely to undergo intraparticle, interparticle, and interstrand rearrangements (Mellema et al., 2002). The ultimate result of such rearrangements is syneresis (expulsion of whey; Mellema et al., 2002). The rate and extent of syneresis is promoted by various cheese-making processes, such as cutting, stirring, scalding, and pressing (Dejmek and Walstra, 2004). Syneresis is considered as an essential step during cheese manufacture because it affects the composition and texture of final cheese, as reviewed extensively by Dejmek and Walstra (2004). However, in some cheese types, such as Quark (also called Quarg) and cottage cheese, syneresis can also occur in the finished product during storage, termed wheying-off, which is generally considered as undesirable (Guinee, 2016).

To date, there is significant knowledge on how milk composition and renneting conditions affect the gel structure. However, the link between gel structure and macroscopic behavior of the gel, such as syneresis and water-holding, is not yet fully understood. Structural parameters, such as dimensions of protein strands, network pore size, and volume fraction of the pores and protein network, can be characterized at different structural levels by using different microscopic techniques (Langton and Hermansson, 1996; Ong et al., 2011b). Such structural information is relevant in understanding the effects of milk composition and gelation conditions on the macroscopic behavior of gels, such as syneresis and water-holding properties of gel.

Casein-Mineral Interactions. In cheese, significant levels of minerals are associated with the protein network (Lucey and Fox, 1993). Calcium and phosphate $\left(\mathrm{PO}_{4}\right)$ are the 2 most important minerals found in cheese, and are present in both soluble and colloidal form. However, it is well recognized that the calcium and phosphate associated with the casein are an important structural unit in cheese. The level of calcium associated with casein (micellar calcium) varies widely between cheese types, ranging from less than $5 \mathrm{mg} / \mathrm{g}$ of protein in feta and cottage cheese to $\sim 24 \mathrm{mg} / \mathrm{g}$ of protein in Gouda and Emmental cheese (Remillard and Britten, 2011).

Modulation of levels of colloidal calcium in the cheese matrix can alter the texture and cooking properties of cheese. For example, decreased levels of colloidal calcium is associated with the softening of cheese texture [at least in Cheddar; O'Mahony et al. (2005)] and increased melt and flow properties (O'Mahony et al., 2006; Choi et al., 2008), attributed to the reduction in calcium-induced casein-casein interactions (Lucey et al., 2003). This mechanism is supported by the studies of Pastorino et al. (2003a) and McMahon et al. (2005), who observed a more homogeneous microstructure in cheeses with low levels of calcium than those with high levels of calcium, when observed using scanning electron microscopy; this indicates the proteins in the former are less aggregated than in the latter cheeses.

Micellar calcium levels in cheese are considered important in conferring an elastic texture to cheese (Lucey and Fox, 1993), which is important in the case of eye-forming cheese types, such as Emmental and Gouda, to accommodate gas produced during warmroom ripening for smooth eye formation (Daly et al., 2010). Moreover, an elastic texture is also important for sliceability of cheese without fracturing or crumbling or sticking to cutting implements (Guinee, 2016).

It has also been reported that increased hardness due to increase in micellar calcium levels slowed down the disintegration during in vitro digestion, which in turn can affect nutrient bioaccessibility (Ayala-Bribiesca et al., 2016).

Age-Related Changes in the Protein Matrix. During maturation, the structure of the protein network alters due to complex physical and biochemical changes in the cheese matrix, such as proteolysis by various proteolytic agents, demineralization of casein, and hydration of the casein networks (at least in Mozzarella), as reviewed by Guinee (2016).

Recently, fermentation-produced camel chymosin has received attention because of its much higher ratio of milk clotting to general proteolytic activity than bovine chymosin (Kappeler et al., 2006). Cheddar cheeses made using recombinant camel chymosin were generally found to be harder with less bitter and brothy flavors, and with lower levels of proteolysis than cheeses made from bovine chymosin or microbial rennet (Hannilase; Bansal et al., 2009; Soodam et al., 2015). Moynihan et al. (2014) suggested the use of recombinant camel chymosin to extend the shelf-life performance of lowmoisture partly skim Mozzarella because its baking properties, such as blister quantity, strand thickness, 
hardness, and chewiness, on baked pizzas were maintained for a longer time in storage than in cheeses made with bovine calf chymosin. Apart from residual coagulants, indigenous milk enzymes and enzymes produced by starter and nonstarter bacteria also contribute to the proteolysis of cheese, particularly in high-cooked cheese varieties in which the residual chymosin activity is very low, most probably due to heat denaturation of chymosin (Sousa et al., 2001; Sheehan et al., 2007). Plasmin is considered the most important indigenous milk proteolytic enzyme, and its activity in highcook cheese varieties (e.g., Emmental and grana-type cheeses) is comparatively higher than those in low-cook cheese varieties, (e.g., Cheddar), most probably due to thermal inactivation of inhibitors of both plasminogen activators and plasmin (Sheehan, 2013). Plasmin has an optimum $\mathrm{pH}$ of $\sim 7.5$ and thus makes a major contribution to the ripening of cheese types with high $\mathrm{pH}(\sim 7)$, such as mold-ripened (e.g., Camembert) and smearripened (e.g., Tilsit) cheese varieties (McSweeney, 2004; Sheehan, 2013). The role of plasmin and other indigenous milk enzymes in casein hydrolysis and their contribution to the quality of cheese has been reviewed extensively (Sousa et al., 2001; Kelly and McSweeney, 2003; McSweeney, 2004; Kelly et al., 2006).

Varying degree of hydrolysis of casein in different cheese types have been reported (Table 1 ). The rate and extent of casein hydrolysis is influenced by factors, such as cheese type, ripening temperature, level and types of coagulant, and cheese compositions (e.g., moisture in nonfat substance, Table 1). $\alpha_{S 1}$ Casein has been considered to be the principal structural element in several cheese varieties, such as Cheddar and Emmental (Lawrence et al., 1987; Gagnaire et al., 2002), with the hydrolysis of $\alpha_{\mathrm{S}_{1}} \mathrm{CN}$ thus being associated with a weakening of the protein network (Creamer and Olson, 1982). However, more recent studies have shown that softening of cheese in the early stages of ripening is primarily due to solubilization of CCP (O'Mahony et al., 2005).

Some studies indicated that the specific hydrolysis patterns of casein and the resulting peptide profiles can influence the melting and stretching properties of cheese. For example, Bogenrief and Olson (1995) observe a degree of melt of Cheddar cheese is more closely related to the extent of $\beta$-CN hydrolysis than the hydrolysis of $\alpha_{S 1}$-CN. In another study, Emmental cheeses made with Lactobacillus helveticus as a starter culture exhibited greater stretchability (2.5 times higher) than those with Lactobacillus delbrueckii (Richoux et al., 2009). Moreover, the stretchability of cheese was strongly correlated with the proportion of hydrophobic peptides in the $\mathrm{pH}$ 4.6-soluble nitrogen fraction. This finding is further supported by the study of Sadat-Mekmene et al. (2013), who also observed high stretchability in Swiss-type cheese made with 2 different strains of Lactobacillus helveticus (i.e., ITGLH77 and ITGLH1). Moreover, the stretchability was correlated with hydrophobic peptides, regardless of casein origin (i.e., whether $\alpha_{\mathrm{S}_{1}} \mathrm{CN}, \alpha_{\mathrm{S}_{2}} \mathrm{CN}$, or $\beta-\mathrm{CN}$ ), and with a lower degree of proteolysis. These hydrophobic peptides may interact with the protein matrix or with other large peptides via hydrophobic forces, possibly forming fibers in the cheese matrix (Richoux et al., 2009).

\section{Fat Phase}

During cheese manufacture, milk fat globules are entrapped within the protein gel network, and processes such as scalding, cheddaring, hot water stretching, and pressing, can cause aggregation, coalescence, and disruption of the fat globules. In the cheese matrix, fat globules can exist as intact (spherical fat globules covered with native membrane materials), aggregated (clumps of circular fat globules), coalesced (spherical but larger than typical milk fat globules), elongated (especially in pasta-filata cheese-types), or even nonglobular forms (Michalski et al., 2007; Rogers et al., 2010; Ong et al., 2011b) (Figure 2). The microstructure of fat globules can influence the physical properties of cheese. For example, although Everett and Olson (2003) did not find a correlation between fat-globulecircularity and free-oil formation in Cheddar cheese, fat globule size (Feret's diameter) in Mozzarella cheese has been positively correlated with meltability and free oil in a study by Ma et al. (2013).

Several factors, such as fatty acid compositions, native milk fat globule (NMFG) size, level of fat, and properties of fat globule membrane materials, can influence various properties of cheese.

Fatty Acid Composition. The fatty acid composition of milk fat [which is influenced by factors such as stage of lactation, breed of cow, genetics, and diet composition, Månsson (2008)] can alter the rheological and textural properties of cheese. Palmitic acid (C16:0) and oleic acid (C18:1) are the major saturated and unsaturated fatty acids in milk that have high and low melting points, respectively (Coppa et al., 2011); a higher ratio of C18:1 to C16:0 is known to produce more creamy and less firm cheese (Coppa et al., 2011; Bocquel et al., 2016). Bocquel et al. (2016) observed $\sim 30 \%$ decrease in hardness of Raclette cheese when the ratio of C18:1 to C16:0 in cheese milk increased from 0.8 to 1.0. In the case of Raclette cheese, increased hardness increases the risk of cracks forming, which significantly affects the quality of cheese (Bocquel et al., 2016). The effect of fatty acid composition on the mouthfeel of cheese is not yet fully understood. However, it may be assumed 
TEAGASC/UNIVERSITY COLLEGE CORK CHEESE SYMPOSIUM

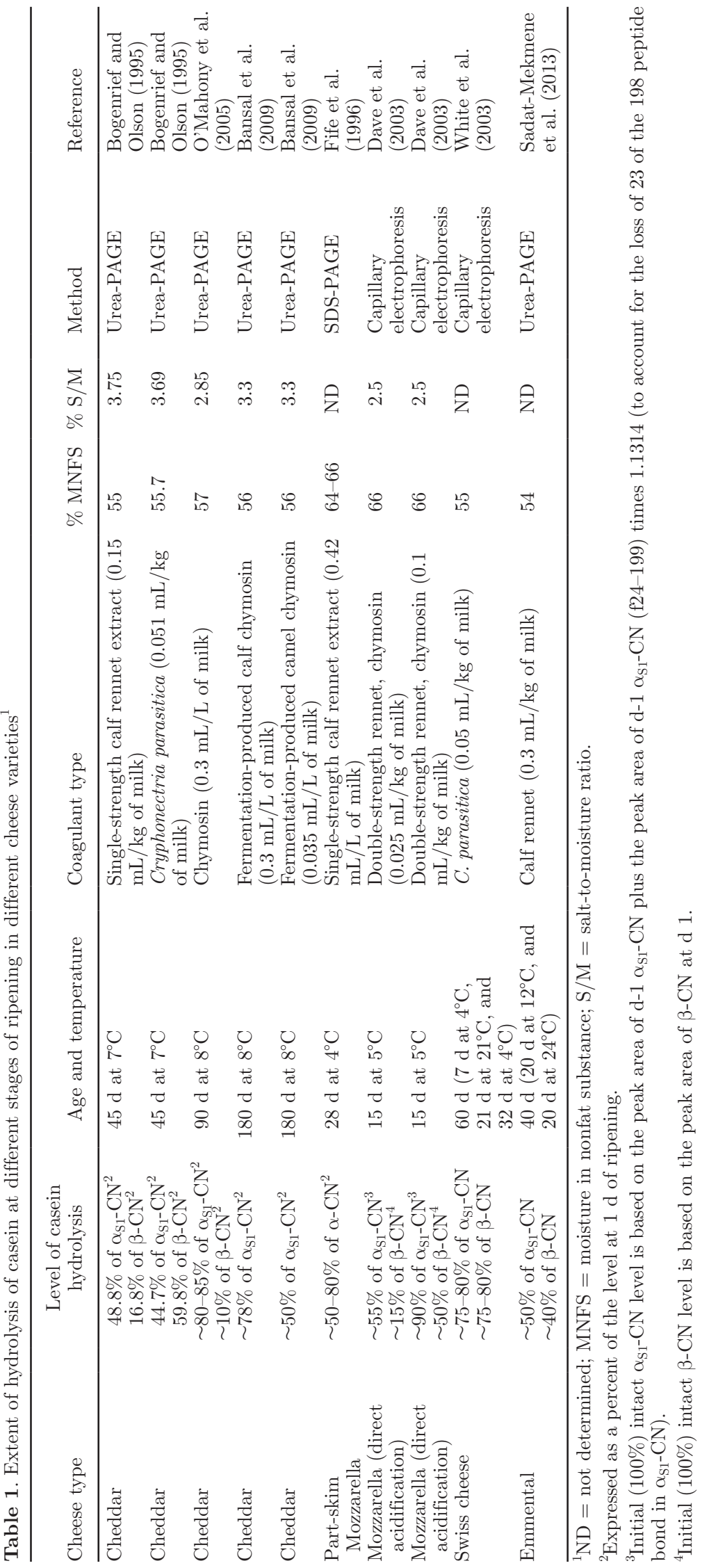


that the complex crystallization behavior due to fatty acid composition can alter the in-mouth coalescence of fat globules during oral processing, which can in turn affect the fat-related sensory perception. For example, high solid fat content in emulsion droplets enhances the coalescence of emulsion droplets and reduces friction during oral processing of emulsion-filled gels (Liu et al., 2015).

Native Milk Fat Globule Size. The size of NMFG ranges from $<0.2$ to $>15 \mu \mathrm{m}$, with an average diameter of $\sim 4 \mu \mathrm{m}$ (Huppertz and Kelly, 2006). Studies have shown that the cheese manufactured from milk with different fat globule size differ compositionally and texturally. For example, Camembert and Emmental cheese produced from milk with small fat globules (SFG, $\sim 3 \mu \mathrm{m}$ ), separated using microfiltration, had higher
A

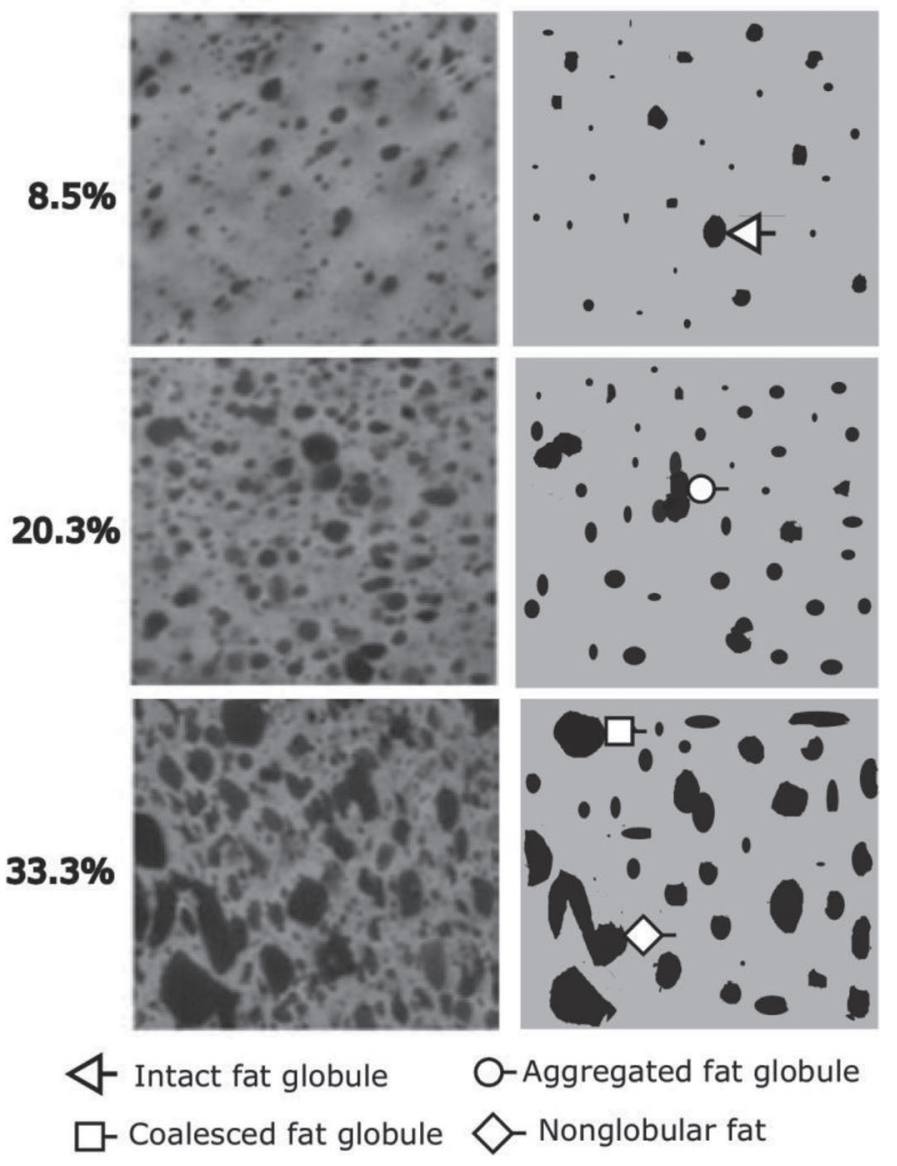

Figure 2. Column A shows the confocal laser scanning microscopy images $(100 \mu \mathrm{m} \times 100 \mu \mathrm{m})$ of Cheddar cheese (age: $12 \mathrm{wk})$ at 3 different fat levels $(8.5,20.3$, and $33.3 \%$ ). Column B is the schematic representation of Cheddar cheese microstructure, with intact fat globules, aggregated fat globules, coalesced fat globules, and nonglobular fats. The dark and gray areas represent fat globules and protein network within the cheese matrix, respectively. Adapted from Rogers et al. (2010) with permission. Copyright (2010) American Dairy Science Association. moisture content, softer texture, and underwent greater proteolysis during ripening than cheese made from milk with large fat globules (LFG, $\sim 6 \mu \mathrm{m}$; Michalski et al., 2003, 2004). More recently, Logan et al. (2017) reported that the Cheddar cheese made from milk with SFG $(\sim 2.7 \mu \mathrm{m})$ was less firm at the early stages of ripening, and was less cohesive, less chewy, and less springy throughout maturation than cheese made from milk with LFG $(\sim 5 \mu \mathrm{m})$. However, the exact effect of NMFG size on cheese properties was not determined in these studies because the effect of NMFG size is confounded with the cheese moisture level.

In another study, Michalski et al. (2007) made Emmental cheeses from milk with SFG and control milk, and adapted the process to obtain similar moisture content. The authors found that Emmental cheeses with SFG exhibited higher stretchability and elasticity, and improved sensory characteristics compared with control cheeses, despite the moisture content being similar for both cheeses. This may be attributed to the effect of NMFG size on microstructure of cheese. Emmental (Michalski et al., 2007) and Cheddar (Logan et al., 2017) cheeses made from SFG appeared less aggregated and less coalesced than control cheeses or cheeses made from LFG, when observed using confocal laser scanning microscopy. Moreover, more intact fat globules covered with phospholipids were observed in Cheddar cheeses from SFG than those from LFG when observed using confocal laser scanning microscopy (Logan et al., 2017). A recent study of an emulsion-filled gel system has reported that the mechanical properties of emulsion gels are influence by the magnitude of droplet clustering or aggregation. Droplet clustering or aggregation enhanced the stiffness of emulsion-filled gels (Oliver et al., 2015).

Moreover, the fat globule size can alter the casein strand formation during rennet-induced coagulation of milk; this could be another reason for observed differences in the properties between the cheeses made from milk with small and large fat globules. Depending on the size of NMFG and the pore size of the protein network, the NMFG can act as an "inert-filler," "structure-breaker" (Michalski et al., 2002), or has even been suggested as being held weakly within the protein matrix (Everett and Olson, 2000; Logan et al., 2015).

Level of Fat. A reduction in levels of fat without a proportionate increase in the levels of moisture will increase the concentration of casein in the protein matrix, leading to a compact protein matrix and a lower degree of fat coalescence (at least in Cheddar; Guinee et al., 2000; Rogers et al., 2010; Figure 2). Such changes on the cheese structure may have consequences for texture, opacity, and rheological and cooking properties of cheese (Guinee et al., 2000; Johnson et al., 2009; Rogers 
et al., 2009; Rogers et al., 2010). The effect of fat reduction on texture, flavor, cooking properties, and color of cheese has been reviewed by Johnson et al. (2009).

To better understand the role of milk fat content on the mechanical and rheological properties of cheese, and to simplify the complex cheese system, model filler particles, such as Sephadex beads (Barden et al., 2015) or glass beads (Thionnet et al., 2017), have been used instead of milk fat in some studies. These studies suggested that the mechanical properties of cheese depend on the rheological properties of both the gel matrix and filler particle and on the volume within the cheese occupied by the filler particles (Barden et al., 2015; Thionnet et al., 2017). This knowledge may be useful in developing the replacement of milk fat in low-fat cheeses with other fat-like components, such as hydrocolloids (Thionnet et al., 2017).

Interactions Between Fat Globules and Protein Matrix. The interactions between milk fat globules and the protein matrix in cheese largely depend on the composition of fat globule membrane materials. Although a subject of debate (Everett and Auty, 2008), it is generally accepted that the NMFG membrane, which is composed mainly of specific proteins and phospholipids, does not chemically interact with the surrounding protein matrix (Michalski et al., 2002).

The nature and extent of interactions between fat globules and protein network can be controlled by modifying the surface properties of fat globules. Such modulation of fat-protein interactions can alter the cheese structure, which in turn can affect the mechanical, rheological, and sensorial properties of cheese. For example, Everett and Olson (2003) compared the microstructure and rheological properties of Cheddar cheese manufactured from recombined milk containing fat globules coated with casein or whey proteins. The microstructure of fat globules appeared elongated and clustered in cheeses made from milk with fat globules coated with $\alpha_{S_{2}}-\mathrm{CN}$ (a relatively poor emulsifier) compared with other experimental cheeses in which fat globules were coated with other proteins. Moreover, the former cheeses fractured at a lower strain and with a lower stress than the other experimental cheeses.

The effect of interactions between fat globules and protein matrix on texture perception of cheese is not yet fully understood. However, several studies on emulsion-filled gel systems reported a significant effect of filler-matrix interactions on the texture perception. Emulsion-filled gels are prepared by embedding emulsion droplets into a gel matrix, and are a representative model food system for a broad variety of food products, including cheese (Sala et al., 2007). Depending on the properties of the emulsifiers on the surface of emulsion droplets, emulsion droplets can either be bound to the gel matrix (called bound filler) or not (called unbound filler; Sala et al., 2007). Unbound fat has been found to be related to the enhancement of fat-related sensory perception rather than bound fat droplets in emulsionfilled gels (Sala et al., 2007; Liu et al., 2015). The unbound droplets underwent more coalescence than bound droplets during oral manipulation, leading to lower friction and enhancement of fat-related sensory perceptions (Liu et al., 2015).

\section{Aqueous/Serum Phase}

Water. Water in cheese can be broadly classified as bound or bulk water. Bound water is strongly associated with protein and other components of the cheese matrix, and this water is not available as a solvent, whereas bulk water is loosely associated within the protein matrix and retains a large solvent capacity and is freezable at $-40^{\circ} \mathrm{C}$ (McMahon et al., 1999). Bulk water may be either present within the channels surrounding the fat (free water) or entrapped within the protein matrix (entrapped water). The distribution and state of water in cheese depends on factors such as cheese-type and age. In most cheese varieties, most of the water is present within the protein matrix. However, in young Mozzarella cheese, a significant amount of water is present in the fat-serum channel. During aging, this water is gradually absorbed into the protein matrix, which has been confirmed by studies undertaken using nuclear magnetic resonance technique (Kuo et al., 2001; Smith et al., 2017). Moreover, during maturation, hydrolysis of each peptide bond releases 2 new charged groups $\left(\mathrm{NH}_{3}{ }^{+} / \mathrm{COO}^{-}\right)$that can bind the available free water and thus can alter the state of water in cheese (Creamer and Olson, 1982). This might be a possible reason for a slight decrease in water activity $\left(a_{w}\right)$ in Cheddar cheese during ripening, from a mean of $\sim 0.965$ at $1 \mathrm{~d}$ to $\sim 0.956$ at $270 \mathrm{~d}$ (Hickey et al., 2013).

Cheese generally becomes softer as the levels of moisture increase. Two main reasons have been reported for the texture softening effect of moisture: (1) water in the cheese matrix plays the role of a plasticizer (low-viscosity lubricant; Marshall, 1990), and (2) increasing the levels of moisture results in a corresponding decrease in the levels of casein, which is the principal structuring component (McMahon et al., 2005). However, the effect of water on melt properties of cheese is rather complex. Increasing total moisture content of cheese does not necessarily increase the meltability of cheese (Pastorino et al., 2003c; McMahon et al., 2005). Instead, melt properties of cheese are reported to be more related to casein-water interactions (which are largely influenced by $\mathrm{pH}$, ionic strength, and the levels of $\mathrm{CCP}$ ) than total moisture content (McMahon et al., 1999). 
Components of the Aqueous/Serum Phase. The components present in the aqueous phase, such as nitrogen fractions (water-soluble protein, enzymes, peptides, or free AA), minerals, carbohydrates (lactose, galactose, and glucose) and organic acids, and their level influence the environment, mainly $\mathrm{pH}, \mathrm{a}_{\mathrm{w}}$, and ionic strength, of the cheese matrix (Salaün et al., 2005; Hickey et al., 2013). This can in turn affect the structure of the protein phase in cheese and thus on the texture, rheological, and cooking properties. Moreover, the correct balance and concentration of components of the serum phase can influence the flavor profile of cheese. Components, such as hydrophobic peptides, lactose, lactate, and free AA, have been found to be positively associated with bitter, sweet, sour, and umami flavor intensities, respectively (Møller et al., 2013).

The level of ions and their valance determines the ionic strength of serum phase of the cheese matrix, which can alter protein interactions. Salt $(\mathrm{NaCl})$ has a major contribution to the ionic strength of the cheese matrix, because a varying amount of salt, ranging from $\sim 0.5 \%$ (wt/wt) to $6 \%$ (wt/wt), is added in cheese, mainly for flavor and preservation (Guinee, 2004). Addition of salt up to certain concentrations can promote proteinwater interactions, probably due to a "salting-in" effect, leading to hydration and swelling of the casein matrix (Guinee, 2004). Several studies have elucidated the role of salt in hydration and solubilization of casein. Guo et al. (1997) observed a higher levels of intact casein in the serum phase obtained from centrifugation $(\sim 12,500$ $\times \mathrm{g}$ for $75 \mathrm{~min}$ at $25^{\circ} \mathrm{C}$ ) of brine-salted Mozzarella cheese than in unsalted cheese. Pastorino et al. (2003b) observed a more homogeneous protein matrix with less serum pockets in Munster cheese injected with salt than cheese without salt injection, as observed by scanning electron microscopy. Everett et al. (2014) reported an increase in $\mathrm{NaCl}$-soluble proteins with increasing concentration of salt solution up to $6 \%$ (wt/wt) when unsalted Cheddar curd was immersed in varying brine concentrations $(0-25 \%$, wt/wt). However, very high salt concentrations can promote protein-protein interactions, probably due to a "salting-out" effect, leading to protein aggregation and contraction of the cheese matrix.

Salt in the cheese matrix not only contributes to the saltiness of cheese, but can also enhance the flavor intensity of sapid compounds; moreover, salt can suppress the unwanted flavor, e.g., bitterness (Møller et al., 2013). Thus, reduction in salt content is sometimes associated with flavor defects. For example, the flavor profile of Cheddar cheese deteriorated when the level of salt was reduced by 50\% (Møller et al., 2013). In another study, consumer liking for low-salt cheeses was low and they were able distinguish even a $30 \%$ salt reduction (Ganesan et al., 2014).

The effect of salt in structure, texture, rheological, and cooking properties of cheese has been discussed extensively (Guinee, 2004; Everett et al., 2014). A general overview of the role of salt in cheese is depicted in Figure 3.

\section{Gas Phase (Particularly Carbon Dioxide)}

Formation of smooth eyes in eye-forming cheese types, such as Emmental and Maasdam, is considered an important quality parameter. Cheese matrix structure, the rate and extent of gas production and its behavior in the cheese matrix (e.g., solubility and diffusivity), and the presence of nuclei are known to play an important role in desirable eye formation (Daly et al., 2010). In this section of review, we focus on the role of $\mathrm{CO}_{2}$ in the eye formation.

An appropriate understanding of $\mathrm{CO}_{2}$ production, and its solubility and diffusivity in the cheese matrix, is necessary to obtain desirable quality of eyes without splits and cracks. Carbon dioxide in the cheese matrix is mainly produced due to lactate fermentation by propionic acid bacteria during the warm room ripening. The rate and extent of $\mathrm{CO}_{2}$ production is influenced by factors, such as strains of propionic acid bacteria, ripening temperature, and cheese composition (Daly et al., 2010). Acerbi et al. (2016a) determined the rate of production of $\mathrm{CO}_{2}$ in semi-hard cheese to be $\sim 10$ to 15 $\mathrm{mmol} / \mathrm{kg} \cdot \mathrm{d}$ at constant temperature $\left(25^{\circ} \mathrm{C}\right)$ and salt-tomoisture ratio $(2 \%$, wt/wt). Carbon dioxide solubilizes in the fat and aqueous phases of cheese. However, its solubility is largely temperature dependent [i.e., the solubility of $\mathrm{CO}_{2}$ in the fat phase is lower at low temperature (e.g., $4^{\circ} \mathrm{C}$ ) than at high temperature (at least up to $20^{\circ} \mathrm{C}$ )]; the opposite holds true for the solubility of $\mathrm{CO}_{2}$ in water (Jakobsen et al., 2009). The solubility of $\mathrm{CO}_{2}$ in semi-hard cheese was determined as $\sim 37$ $\mathrm{mmol} / \mathrm{kg} \cdot \mathrm{atm}$ at $2^{\circ} \mathrm{C}$ and $\sim 30 \mathrm{mmol} / \mathrm{kg} \cdot \mathrm{atm}$ at $25^{\circ} \mathrm{C}$ (Acerbi et al., 2016b). Thus, any changes in the ripening conditions or cheese composition or both can alter the solubility of $\mathrm{CO}_{2}$ within the cheese matrix, which in turn can affect the internal pressure of cheese. It is necessary to control the internal pressure of cheese, because overpressure can lead to slits or cracks, which are unappealing to consumers. Moreover, these cheeses can produce a lot of fines or broken portions during size reduction operations, such as slicing and dicing, resulting in lost revenue to manufacturers (Martley and Crow, 1996). On the other hand, small or no eyes ("blind" cheese) will be formed if the gas pressure is inadequate. 


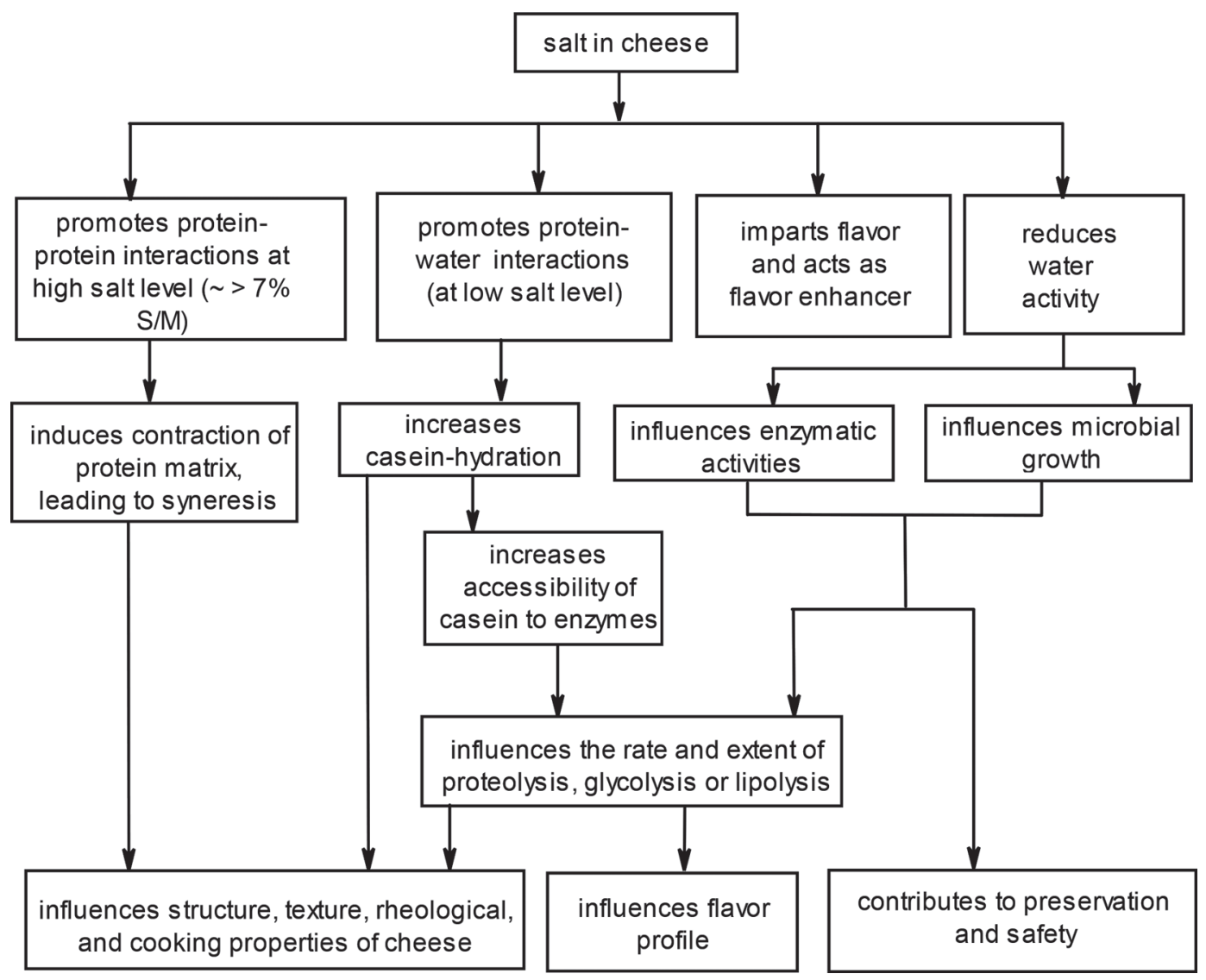

Figure 3. Role of salt in cheese. $\mathrm{S} / \mathrm{M}=$ salt-to-moisture ratio.

Carbon dioxide produced in the cheese matrix diffuses within the cheese matrix or escapes from the cheese. The diffusion of $\mathrm{CO}_{2}$ within the cheese is thought to obey the second law of Fick [Equation [1]; where D is the effective diffusivity coefficient $\left.\left(\mathrm{m}^{2} / \mathrm{s}\right)\right]$, which describes the change in concentration (c) with time (t) at any place $(\mathrm{x})$ as a function of the local concentration gradient for a mono-directional diffusion (Acerbi et al., 2016c).

$$
\frac{d c}{d t}=D\left(\frac{d^{2} c}{d x^{2}}\right)
$$

Diffusion of $\mathrm{CO}_{2}$ to nuclei generates pressure at nuclei which are the primary site for eye formation. Diffusivity of $\mathrm{CO}_{2}$ within the cheese matrix is one of the most important factors affecting eye growth in eye-forming cheese types, and it is influenced by cheese composition and structure, and ripening conditions. For example, a higher level of diffusivity of $\mathrm{CO}_{2}$ has been observed in more aged semi-hard cheeses compared with young cheeses, and this has been attributed to age-related changes in the cheese matrix, such as proteolysis and demineralization of casein (Acerbi et al., 2016c).

\section{EFFECT OF ENVIRONMENTAL FACTORS ON STRUCTURAL AND FUNCTIONAL PROPERTIES OF CHEESE}

\section{$\mathrm{pH}$}

It is widely recognized that $\mathrm{pH}$ has a strong influence on the texture, rheological, and cooking properties of cheese, mainly via altering the casein-casein, mineralcasein, and casein-water interactions, through its effect on casein charge and calcium solubility. At higher $\mathrm{pH}$ values $(\sim 5.4)$, the proportion of calcium associated with casein (micellar calcium) is relatively higher than at low $\mathrm{pH}$ [unless colloidal calcium is solubilized by other means, such as addition of calcium chelators; Choi et al. (2008); McAuliffe et al. (2016)]. Higher levels of micellar calcium promote casein-casein interactions within the cheese matrix. Such strong casein-casein interactions are known to increase the structural rigidity of the cheese matrix; as a consequence, cheese tends 
to be more firm, elastic, and less meltable (McMahon et al., 2005). At intermediate $\mathrm{pH}(\sim 5.1)$, casein-casein interactions decrease as the negatively charged regions of the casein (e.g., phosphoserine residues) are exposed due to partial solubilization of micellar calcium, and the resultant cheese tends to be softer and more meltable (Lucey et al., 2003). However, lowering the $\mathrm{pH}$ toward 4.7 increases the strong casein-casein interactions as the casein approach their isoelectric point, and adversely affects the melt, flow, and stretch properties of cheese (Lucey et al., 2003; Pastorino et al., 2003a).

It seems that that $\mathrm{pH}$ may have an indirect effect related to its influence on the distribution of calcium (soluble or casein-associated) at $\mathrm{pH}$ above 5 (at least in Cheddar and direct-acidified nonfat Mozzarella cheese; Pastorino et al., 2003a; McMahon et al., 2005). Below 5, pH seems to have a direct effect (i.e., charge neutralization). If the cheese curd has very low levels of calcium, then increasing $\mathrm{pH}$ may simply increase protein-water interactions, probably due to increases in electrostatic repulsion forces between the charged groups of protein, which is illustrated by the work of Monteiro et al. (2009). Those authors investigated the effect of $\mathrm{pH}$ on the microstructure and functionality of hot-pack cream cheese, in which calcium level is very low, by using exposure to acetic acid or ammonia vapor to modulate $\mathrm{pH}$ after manufacture. The microstructure of cheese appeared more continuous or swollen with increasing $\mathrm{pH}$ (Figure 4), indicating that the casein is increasingly hydrated with increasing $\mathrm{pH}$; moreover, cheese firmness decreased, whereas cheese meltability increased, with increasing $\mathrm{pH}$.

The $\mathrm{pH}$ of cheese can alter the size of the protein aggregates and their arrangement in the protein matrix (Hall and Creamer, 1972; Lawrence et al., 1987; Pastorino et al., 2003a). Pastorino et al. (2003a) developed a model for the protein matrix of cheese at different $\mathrm{pH}$, and reported that the diameter of protein aggregates were relatively higher at $\mathrm{pH} 5.3$ (10 to $12 \mathrm{~nm}$ ) than at pH 4.7 (2 to $4 \mathrm{~nm}$ ) in their model. Moreover, the protein aggregates at $\mathrm{pH} 5.3$ have relatively more well-defined structure than those at $\mathrm{pH}$ 4.7. The proposed model is in agreement with the study of Hall and Creamer (1972), who observed bigger protein aggregates (10 to $15 \mathrm{~nm})$ in Gouda cheese (pH, 5.3) than in Cheshire cheese $(3$ to $4 \mathrm{~nm})$, with relatively low $\mathrm{pH}(\sim 4.6)$, when examined using scanning electron microscopy; moreover, the protein in latter cheese is less well organized. Taneya et al. (1992) also reported a less well-defined protein network structure of curd at $\mathrm{pH} 5.0$ than at $\mathrm{pH}$ 5.4 when observed with transmission electron microscopy, and the authors concluded that curd having $\mathrm{pH} 5.4$ is suitable for stretching during manufacture of string cheese. Pastorino et al. (2003a) speculated that the size of the protein aggregates and their arrangement in the cheese matrix may alter the texture, rheological, and cooking properties of cheese because the strength of material is known to be influenced by factors such as the extent of cross-linking, and the orientation or the structural regularity of the constituents of the material (Pastorino et al., 2003a).

It is well known that mold-ripened cheeses (e.g., Camembert and Brie), have a macroscopic $\mathrm{pH}$ gradient between the surface and interior of cheese (McSweeney, 2004). However, it has recently been found that cheese can have a microscopic $\mathrm{pH}$ gradient. Burdikova et al. (2015) observed $\mathrm{pH}$ micro-heterogeneity in natural cheese matrices using fluorescence lifetime imaging microscopy (Figure 5). The local variation of $\mathrm{pH}$ in cheese matrix may influence the molecular interactions at local level, which may lead to local heterogeneity in the microstructure of cheese. Nevertheless, more research is needed to gain greater understanding in this area.

\section{Temperature}

Temperature influences the structure of cheese through its effect on the components of cheese and their interactions, including changes in the physical state of fat and the molecular interactions between the casein. These changes in the structure of cheese are important to the textural, rheological, and cooking properties of heated or unheated cheese. At low temperatures (below
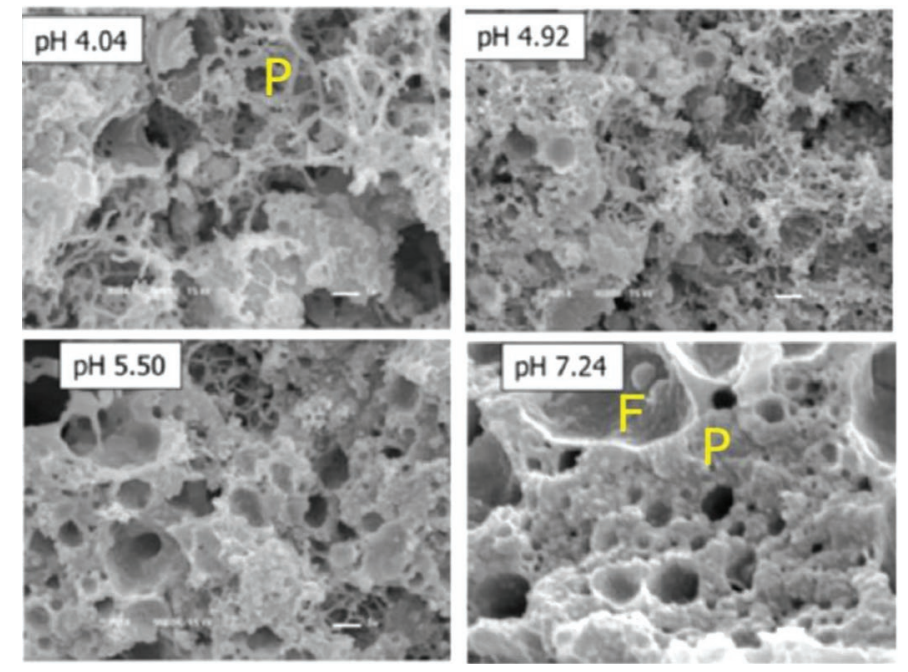

Figure 4. Scanning electron micrographs $(9,000 \times)$ of hot pack cream cheese with different $\mathrm{pH}$ values. Cheese sample were exposed to ammonia vapor to increase the $\mathrm{pH}$ or acetic acid vapor to decrease the $\mathrm{pH}$. The $\mathrm{pH}$ of the untreated control cheese was 4.92 . $\mathrm{P}=$ protein matrix, $\mathrm{F}=$ spherical imprints in the protein matrix left by fat globules that were extracted during sample preparation. Scale bar represents 1 $\mu \mathrm{m}$. Adapted from Monteiro et al. (2009) with permission. Copyright (2009) Institute of Food Technologists. Color version available online. 
$20^{\circ} \mathrm{C}$ ), a significant proportion of milk fat is in a solid state (Lopez et al., 2006). Lopez et al. (2006) observed more than half ( $\sim 54 \%$ of total fat content) of the milk fat present in Emmental cheese is in crystallized form at $4^{\circ} \mathrm{C}$. Solid milk fat in cheese is known to act as reinforcing fillers, contributing to elastic properties of unheated cheese (Rogers et al., 2010; Shima and Tanimoto, 2016). Moreover, it has been suggested that the contact area between the casein increases with decreasing temperature as they expand at low temperature, probably due to weakening of hydrophobic interactions (Lucey et al., 2003). Thus, the firmer texture of cheese at low temperature $\left(<20^{\circ} \mathrm{C}\right)$ is considered due to the combined effect of higher proportion of solid fat and increased contact area between casein. The firm texture of cheese at low temperature is generally suitable for size reduction operation because it is easier to cut cheese cleanly (Lucey, 2008).

During heating of cheese, the proportion of liquid fat increases dramatically; at $\sim 40^{\circ} \mathrm{C}$, almost all fat in cheese is in a liquid state (Lopez et al., 2006). Liquid fat acts as a plasticizer between casein strands, making cheese more soft and flexible (Shima and Tanimoto, 2016). Although fat has an important role in the initial softening of cheese during heating, it is now well accepted that the casein interactions have a major role on the melting properties of cheese. Lucey et al. (2003) proposed a mechanism for melting of cheese during heating based on the dual-binding model pro-

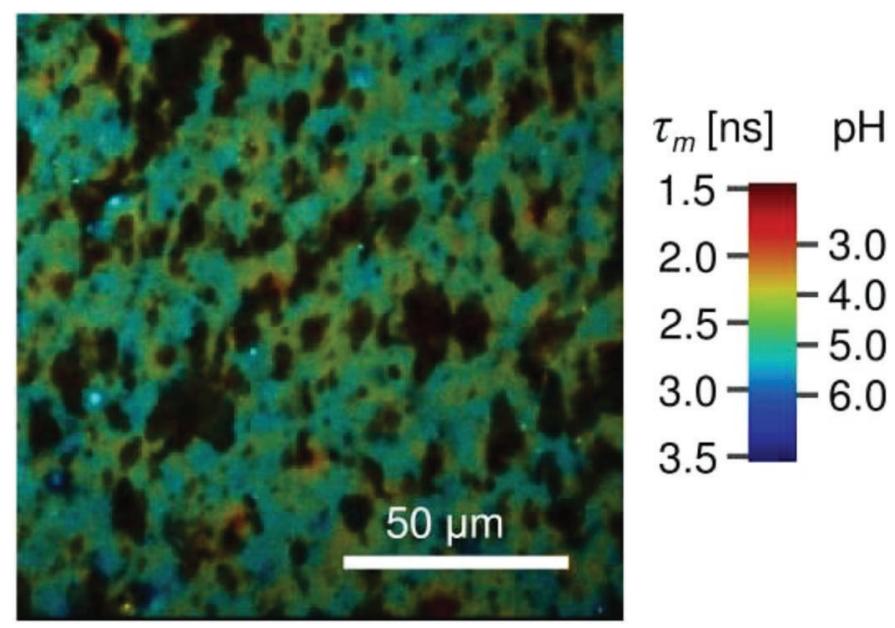

Figure 5. Fluorescence lifetime imaging microscopy (FLIM) image of natural cheese sample stained with Oregon Green 488. Shown are apparent local variations of fluorescence lifetime and thus $\mathrm{pH}$. Localized spots with $\mathrm{pH}$ as low as 4.0 are observed. The dark areas most likely represent fat within the cheese matrix. The pseudocolor scale of the FLIM images is calibrated both in lifetime $\left(\tau_{m}\right)$ and $\mathrm{pH}$ values. Reprinted with permission from Burdikova et al. (2015). Copyright (2015) Lausanne: Frontiers Research Foundation. Color version available online. posed by Horne (1998). The authors speculated that the localized balance of the attractive and repulsive forces between casein controls the cheese melting and the behavior of cheese at elevated temperature. During heating, casein networks in cheese are thought to contract, probably due to strengthening of hydrophobic interactions. Magnetic resonance studies have also indicated that contraction of the protein network occurs in cheese with increasing temperature, since levels of free water in cheese increased as it was heated from 20 to $60^{\circ} \mathrm{C}$ (Vogt et al., 2015; Smith et al., 2017). Contraction of the casein network is suggested to reduce the size of the contact area between casein, leading to weakening of the cheese matrix (Lucey et al., 2003). Weakening of the cheese matrix during heating is indicated by the changes in the rheological parameters, that is, decreases in dynamic moduli $\left(\mathrm{G}^{\prime}\right.$ and $\left.\mathrm{G}^{\prime \prime}\right)$ and an increase of loss tangent with increasing temperature. More recently, mid-infrared and synchronous fluorescence spectroscopies, coupled with chemometrics, have been suggested as valuable tools for understanding the role of temperature on the melt behavior of cheese (Boubellouta and Dufour, 2012).

Kim et al. (2011) investigated the effect of baking temperature $\left(180^{\circ} \mathrm{C}\right.$ for $\left.25 \mathrm{~min}\right)$ on the properties of reduced-fat and full-fat Cheddar cheeses by reacting heated cheeses with different dissociating agents, such as SDS, EDTA, and urea; the results indicated that the skin formation in reduced-fat cheeses is the result of a high degree of protein-protein interactions, which involve disulfide bonds and hydrophobic interactions and, to some extent, ionic bonds with calcium.

\section{CONCLUSIONS}

This review documents the current understanding on structure-function relationships in cheese. A fundamental knowledge of how the structure of cheese influences various functionalities is necessary to design cheeses with enhanced physico-chemical properties, and of optimal sensory and nutritional quality. Such knowledge is particularly important for the improvement of the quality of cheeses such as those with low fat content because fat reduction is often associated with undesirable changes in texture, flavor, and cooking properties. Similarly, reduction in sodium has also been linked particularly with flavor defects. Cheese structures have been shown to play an important role in texture perception and in release of flavor compounds during mastication. Structuring of the cheese matrix for controlled release of nutrients, and delivery of bioactives and probiotics is an area of key importance in the development of functional cheese with beneficial properties beyond basic nutrition. A detailed knowledge of molecular 
interactions and forces that act between cheese components is vital as they can influence the functionality of cheese, such as physico-chemical properties of heated and unheated cheese, and also the release patterns of flavor compounds or nutrients in mouth during mastication or in the gut during digestion. This also creates a need to further develop analytical methods for determination of molecular forces or interactions within the cheese matrix. Similarly, advanced microscopy techniques allied with image analysis, mathematical modeling, and computer simulations will also help to establish a greater knowledge of the link between structure and functionality of cheese. In addition, the growing number of studies using model food systems, such as emulsion-filled gels and solid lipoproteic colloid foods, offers potential, and such approaches need to be applied to research and innovation in natural cheeses. Overall, an appropriate knowledge of structure-function relationship is key to the design of future cheese types with specific functionalities.

\section{ACKNOWLEDGMENTS}

This review was funded by the Dairy Levy Trust, Dublin, Ireland, Teagasc Walsh Fellowship program, Oak Park, Carlow, Ireland, and in part by Ornua, Dubin, Ireland. Prabin Lamichhane is currently in receipt of a Teagasc Walsh Fellowship (RMIS6259).

\section{REFERENCES}

Acerbi, F., V. Guillard, M. Aliani, C. Guillaume, and N. Gontard. 2016a. Impact of salt concentration, ripening temperature and ripening time on $\mathrm{CO}_{2}$ production of semi-hard cheese with propionic acid fermentation. J. Food Eng. 177:72-79. https://doi.org/ 10.1016/j.jfoodeng.2015.12.022.

Acerbi, F., V. Guillard, C. Guillaume, and N. Gontard. 2016b. Impact of selected composition and ripening conditions on $\mathrm{CO}_{2}$ solubility in semi-hard cheese. Food Chem. 192:805-812. https://doi.org/10 .1016/j.foodchem.2015.07.049.

Acerbi, F., V. Guillard, C. Guillaume, M. Saubanere, and N. Gontard. 2016c. An appraisal of the impact of compositional and ripening parameters on $\mathrm{CO}_{2}$ diffusivity in semi-hard cheese. Food Chem. 194:1172-1179. https://doi.org/10.1016/j.foodchem.2015.08.020.

Augustin, M. A., and L. Sanguansri. 2008. Encapsulation of bioactives. Pages 577-601 in Food Materials Science. J. M. Aguilera and P. J. Lillford, ed. Springer, New York, NY.

Ayala-Bribiesca, E., M. Lussier, D. Chabot, S. L. Turgeon, and M. Britten. 2016. Effect of calcium enrichment of Cheddar cheese on its structure, in vitro digestion and lipid bioaccessibility. Int. Dairy J. 53:1-9. https://doi.org/10.1016/j.idairyj.2015.09.002.

Ayala-Bribiesca, E., S. L. Turgeon, and M. Britten. 2017. Effect of calcium on fatty acid bioaccessibility during in vitro digestion of Cheddar-type cheeses prepared with different milk fat fractions. J. Dairy Sci. 100:2454-2470. https://doi.org/10.3168/jds.2016-11902.

Bansal, N., M. A. Drake, P. Piraino, M. L. Broe, M. Harboe, P. F. Fox, and P. L. H. McSweeney. 2009. Suitability of recombinant camel (Camelus dromedarius) chymosin as a coagulant for Cheddar cheese. Int. Dairy J. 19:510-517. https://doi.org/10.1016/j .idairyj.2009.03.010.
Barbé, F., O. Ménard, Y. Le Gouar, C. Buffière, M.-H. Famelart, B. Laroche, S. Le Feunteun, D. Dupont, and D. Rémond. 2013. The heat treatment and the gelation are strong determinants of the kinetics of milk proteins digestion and of the peripheral availability of amino acids. Food Chem. 136:1203-1212. https://doi.org/10 .1016/j.foodchem.2012.09.022.

Barden, L. M., J. A. Osborne, D. J. McMahon, and E. A. Foegeding. 2015. Investigating the filled gel model in Cheddar cheese through use of Sephadex beads. J. Dairy Sci. 98:1502-1516. https://doi .org/10.3168/jds.2014-8597.

Bocquel, D., R. Marquis, M. Dromard, P.-A. Salamin, J. Rey-Siggen, J. Héritier, A. Kosińska-Cagnazzo, and W. Andlauer. 2016. Effect of flaxseed supplementation of dairy cows' forage on physicochemical characteristic of milk and Raclette cheese. Int. J. Dairy Technol. 69:129-136. https://doi.org/10.1111/1471-0307.12235.

Bogenrief, D. D., and N. F. Olson. 1995. Hydrolysis of beta-casein increases Cheddar cheese meltability. Milchwissenschaft 50:678-682.

Boubellouta, T., and É. Dufour. 2012. Cheese-matrix characteristics during heating and cheese melting temperature prediction by synchronous fluorescence and mid-infrared spectroscopies. Food Bioproc. Techol. 5:273-284. https://doi.org/10.1007/s11947-010-0337 -1 .

Burdikova, Z., Z. Svindrych, J. Pala, C. D. Hickey, M. G. Wilkinson, J. Panek, M. A. E. Auty, A. Periasamy, and J. J. Sheehan. 2015 Measurement of $\mathrm{pH}$ micro-heterogeneity in natural cheese matrices by fluorescence lifetime imaging. Front. Microbiol. 6:183. https:// doi.org/10.3389/fmicb.2015.00183.

Choi, J., D. S. Horne, M. E. Johnson, and J. A. Lucey. 2008. Effects of the concentration of insoluble calcium phosphate associated with casein micelles on the functionality of directly acidified cheese. J. Dairy Sci. 91:513-522. https://doi.org/10.3168/jds.2007-0454.

Coppa, M., A. Ferlay, F. Monsallier, I. Verdier-Metz, P. Pradel, R. Didienne, A. Farruggia, M. C. Montel, and B. Martin. 2011. Milk fatty acid composition and cheese texture and appearance from cows fed hay or different grazing systems on upland pastures. J. Dairy Sci. 94:1132-1145. https://doi.org/10.3168/jds.2010-3510.

Creamer, L. K., and N. F. Olson. 1982. Rheological evaluation of maturing Cheddar cheese. J. Food Sci. 47:631-636. https://doi.org/ 10.1111/j.1365-2621.1982.tb10138.x.

Dalgleish, D. G. 1983. Coagulation of renneted bovine casein micelles: Dependence on temperature, calcium ion concentration and ionic strength. J. Dairy Res. 50:331-340. https://doi.org/10.1017/ S0022029900023165.

Dalgleish, D. G., and M. Corredig. 2012. The structure of the casein micelle of milk and its changes during processing. Annu. Rev. Food Sci. Technol. 3:449-467. https://doi.org/10.1146/annurev-food $-022811-101214$.

Daly, D. F. M., P. L. H. McSweeney, and J. J. Sheehan. 2010. Split defect and secondary fermentation in Swiss-type cheeses - A review. Dairy Sci. Technol. 90:3-26. https://doi.org/10.1051/dst/2009036.

Dave, R. I., D. J. McMahon, C. J. Oberg, and J. R. Broadbent. 2003. Influence of coagulant level on proteolysis and functionality of Mozzarella cheeses made using direct acidification. J. Dairy Sci. 86:114-126. https://doi.org/10.3168/jds.S0022-0302(03)73590-5.

Dejmek, P., and P. Walstra. 2004. The syneresis of rennet-coagulated curd. Pages 71-103 in Cheese: Chemistry, Physics and Microbiology. Vol. 1. 3rd ed. P. F. Fox, P. L. H. McSweeney, T. M. Cogan, and T. P. Guinee, ed. Elsevier Academic Press, Amsterdam, the Netherlands.

El-Bakry, M., and J. Sheehan. 2014. Analysing cheese microstructure: A review of recent developments. J. Food Eng. 125:84-96. https:/ doi.org/10.1016/j.jfoodeng.2013.10.030.

Everett, D. W. and M. A. E. Auty. 2008. Cheese structure and current methods of analysis. Int. Dairy J. 18:759-773. https://doi.org/10 .1016/j.idairyj.2008.03.012.

Everett, D. W., T. P. Guinee, and M. E. Johnson. 2014. The importance of salt in the manufacture and ripening of cheese: Cheese structure and functionality. Special Issue of the International Dairy Federation SI-1401, Brussels, Belgium.

Everett, D. W., and N. F. Olson. 2000. Dynamic rheology of renneted milk gels containing fat globules stabilized with different 
surfactants. J. Dairy Sci. 83:1203-1209. https://doi.org/10.3168/ jds.S0022-0302(00)74985-X.

Everett, D. W., and N. F. Olson. 2003. Free oil and rheology of Cheddar cheese containing fat globules stabilized with different proteins. J. Dairy Sci. 86:755-763. https://doi.org/10.3168/jds.S0022 -0302(03)73656-X

Fife, R. L., D. J. McMahon, and C. J. Oberg. 1996. Functionality of low fat Mozzarella cheese. J. Dairy Sci. 79:1903-1910. https://doi org/10.3168/jds.S0022-0302(96)76559-1.

Foegeding, E. A., E. Çakır, and H. Koç. 2010. Using dairy ingredients to alter texture of foods: Implications based on oral processing considerations. Int. Dairy J. 20:562-570. https://doi.org/10.1016/ j.idairyj.2009.12.013.

Foegeding, E. A., and M. A. Drake. 2007. Invited review: Sensory and mechanical properties of cheese texture. J. Dairy Sci. 90:16111624. https://doi.org/10.3168/jds.2006-703.

Gagnaire, V., E. Trotel, Y. L. Graët, and J. Léonil. 2002. Role of electrostatic interactions in the curd of Emmental cheese. Int. Dairy J. 12:601-608. https://doi.org/10.1016/S0958-6946(02)00052-3.

Ganesan, B. K. Brown, D. A. Irish, C. Brothersen, and D. J. McMahon. 2014. Manufacture and sensory analysis of reduced- and lowsodium Cheddar and Mozzarella cheeses. J. Dairy Sci. 97:19701982. https://doi.org/10.3168/jds.2013-7443.

Gierczynski, I., E. Guichard, and H. Laboure. 2011. Aroma perception in dairy products: the roles of texture, aroma release and consumer physiology. A review. Flavour Fragrance J. 26:141-152. https://doi .org/10.1002/ffj.2036.

Gomes da Cruz, A., F. C. Alonso Buriti, C. H. Batista de Souza, J. A. Fonseca Faria, and S. M. Isay Saad. 2009. Probiotic cheese: Health benefits, technological and stability aspects. Trends Food Sci. Technol. 20:344-354. https://doi.org/10.1016/j.tifs.2009.05.001.

Guinee, T. P. 2004. Salting and the role of salt in cheese. Int. J. Dairy Technol. 57:99-109. https://doi.org/10.1111/j.1471-0307 2004.00145.x.

Guinee, T. P. 2016. Protein in cheese and cheese products: Structurefunction relationships. Pages 347-415 in Advanced Dairy Chemistry. Vol. 1B. 4th ed. P. L. H. McSweeney and J. A. O'Mahony, ed. Springer Science+Business Media, New York, NY.

Guinee, T. P., M. A. E. Auty, and M. A. Fenelon. 2000. The effect of fat content on the rheology, microstructure and heat-induced functional characteristics of Cheddar cheese. Int. Dairy J. 10:277-288. https://doi.org/10.1016/S0958-6946(00)00048-0.

Guo, M. R., J. A. Gilmore, and P. S. Kindstedt. 1997. Effect of sodium chloride on the serum phase of Mozzarella cheese. J. Dairy Sci. 80:3092-3098. https://doi.org/10.3168/jds.S0022-0302(97)76279 $-9$

Hall, D. M., and L. K. Creamer. 1972. Study of the sub-microscopic structure of Cheddar, Cheshire and Gouda cheese by electron microscopy. N.Z. J. Dairy Sci. Technol. 7:95-102.

Hickey, D. K., T. P. Guinee, J. Hou, and M. G. Wilkinson. 2013. Effects of variation in cheese composition and maturation on water activity in Cheddar cheese during ripening. Int. Dairy J. 30:53-58. https://doi.org/10.1016/j.idairyj.2012.11.006.

Horne, D. S. 1998. Casein interactions: Casting light on the black boxes, the structure in dairy products. Int. Dairy J. 8:171-177. https://doi.org/10.1016/s0958-6946(98)00040-5.

Horne, D. S., and J. A. Lucey. 2014. Revisiting the temperature dependence of the coagulation of renneted bovine casein micelles. Food Hydrocoll. 42:75-80. https://doi.org/10.1016/j.foodhyd.2013 .12 .021 .

Huppertz, T., and A. L. Kelly. 2006. Physical chemistry of milk fat globules. Pages 173-212 in Advanced Dairy Chemistry. Vol. 2. P. F. Fox and P. L. H. McSweeney, ed. Springer Science+BusinessMedia, New York, NY.

Jakobsen, M., P. N. Jensen, and J. Risbo. 2009. Assessment of carbon dioxide solubility coefficients for semihard cheeses: The effect of temperature and fat content. Eur. Food Res. Technol. 229:287294. https://doi.org/10.1007/s00217-009-1059-3.

Johnson, M. E., R. Kapoor, D. J. McMahon, D. R. McCoy, and R. G. Narasimmon. 2009. Reduction of sodium and fat levels in natural and processed cheeses: Scientific and technological aspects. Com- pr. Rev. Food Sci. Food Saf. 8:252-268. https://doi.org/10.1111/j 1541-4337.2009.00080.x.

Kappeler, S. R., H. M. van den Brink, H. Rahbek-Nielsen, Z. Farah, Z. Puhan, E. B. Hansen, and E. Johansen. 2006. Characterization of recombinant camel chymosin reveals superior properties for the coagulation of bovine and camel milk. Biochem. Biophys. Res. Commun. 342:647-654. https://doi.org/10.1016/j.bbrc.2006.02.014.

Karlsson, A. O., R. Ipsen, and Y. Ardö. 2007. Rheological properties and microstructure during rennet induced coagulation of UF concentrated skim milk. Int. Dairy J. 17:674-682. https://doi.org/10 .1016/j.idairyj.2006.08.002.

Kelly, A. L., and P. L. H. McSweeney. 2003. Indigenous proteinases in milk. Pages 495-521 in Advanced Dairy Chemistry. Vol. 1. 3rd ed. P. F. Fox and P. L. H. McSweeney, ed. Springer US, Boston, MA.

Kelly, A. L., F. O'Flaherty, and P. F. Fox. 2006. Indigenous proteolytic enzymes in milk: A brief overview of the present state of knowledge. Int. Dairy J. 16:563-572. https://doi.org/10.1016/j.idairyj 2005.10.019.

Kethireddipalli, P., and A. R. Hill. 2015. Rennet coagulation and cheesemaking properties of thermally processed milk: Overview and recent developments. J. Agric. Food Chem. 63:9389-9403. https:// doi.org/10.1021/jf504167v

Kim, S. Y., S. Lim, and S. Gunasekaran. 2011. Protein interactions in reduced-fat and full-fat Cheddar cheeses during melting. LWT Food Sci. Technol. 44:582-587. https://doi.org/10.1016/j.lwt.2010 .07 .011

Kuo, M.-I., S. Gunasekaran, M. Johnson, and C. Chen. 2001. Nuclear magnetic resonance study of water mobility in pasta filata and non-pasta filata Mozzarella. J. Dairy Sci. 84:1950-1958. https:// doi.org/10.3168/jds.S0022-0302(01)74637-1

Kuo, W. Y., and Y. Lee. 2014. Temporal sodium release related to gel microstructural properties - Implications for sodium reduction. J. Food Sci. 79:E2245-E2252. https://doi.org/10.1111/1750-3841 .12669 .

Lamothe, S., M.-M. Corbeil, S. L. Turgeon, and M. Britten. 2012. Influence of cheese matrix on lipid digestion in a simulated gastrointestinal environment. Food Funct. 3:724-731. https://doi.org/10 $.1039 / \mathrm{c} 2$ fo $10256 \mathrm{k}$

Langton, M., and A.-M. Hermansson. 1996. Image analysis of particulate whey protein gels. Food Hydrocoll. 10:179-191. https://doi .org/10.1016/S0268-005X(96)80033-6.

Lawrence, G., C. Salles, O. Palicki, C. Septier, J. Busch, and T. Thomas-Danguin. 2011. Using cross-modal interactions to counterbalance salt reduction in solid foods. Int. Dairy J. 21:103-110. https://doi.org/10.1016/j.idairyj.2010.09.005.

Lawrence, R. C., L. K. Creamer, and J. Gilles. 1987. Texture development during cheese ripening. J. Dairy Sci. 70:1748-1760. https:// doi.org/10.3168/jds.S0022-0302(87)80207-2.

Lefebvre-Cases, E., E. Gastaldi, V. Vidal, S. Marchessau, A. Lagaude, J. L. Cuq, and B. T. De La Fuente. 1998. Identification of interactions among casein gels using dissociating chemical agents. J. Dairy Sci. 81:932-938. https://doi.org/10.3168/jds.S0022 -0302(98) 75653-X.

Liu, K., M. Stieger, E. van der Linden, and F. van de Velde. 2015. Fat droplet characteristics affect rheological, tribological and sensory properties of food gels. Food Hydrocoll. 44:244-259. https://doi .org/10.1016/j.foodhyd.2014.09.034.

Logan, A., L. Day, A. Pin, M. Auldist, A. Leis, A. Puvanenthiran, and M. A. Augustin. 2014. Interactive effects of milk fat globule and casein micelle size on the renneting properties of milk. Food Bioproc. Techol. 7:3175-3185. https://doi.org/10.1007/s11947-014 $-1362-2$.

Logan, A., A. Leis, L. Day, S. K. Øiseth, A. Puvanenthiran, and M. A. Augustin. 2015. Rennet gelation properties of milk: Influence of natural variation in milk fat globule size and casein micelle size. Int. Dairy J. 46:71-77. https://doi.org/10.1016/j.idairyj.2014 .08 .005 .

Logan, A., M. Xu, L. Day, T. Singh, S. C. Moore, M. Mazzonetto, and M. A. Augustin. 2017. Milk fat globule size affects Cheddar cheese properties. Int. Dairy J. 70:46-54. https://doi.org/10.1016/ j.idairyj.2016.11.003. 
Lopez, C., V. Briard-Bion, B. Camier, and J.-Y. Gassi. 2006. Milk fat thermal properties and solid fat content in emmental cheese: A differential scanning calorimetry study. J. Dairy Sci. 89:2894-2910. https://doi.org/10.3168/jds.S0022-0302(06)72562-0.

Lucey, J. A. 2008. Some perspectives on the use of cheese as a food ingredient. Dairy Sci. Technol. 88:573-594. https://doi.org/10.1051/ dst:2008010.

Lucey, J. A., and P. F. Fox. 1993. Importance of calcium and phosphate in cheese manufacture: A review. J. Dairy Sci. 76:1714-1724. https://doi.org/10.3168/jds.S0022-0302(93)77504-9.

Lucey, J. A., M. E. Johnson, and D. S. Horne. 2003. Invited review: Perspectives on the basis of the rheology and texture properties of cheese. J. Dairy Sci. 86:2725-2743. https://doi.org/10.3168/jds S0022-0302(03)73869-7.

Ma, X., B. James, L. Zhang, and E. A. C. Emanuelsson-Patterson 2013. Correlating Mozzarella cheese properties to its production processes and microstructure quantification. J. Food Eng. 115:154-163. https://doi.org/10.1016/j.jfoodeng.2012.10.002.

Madziva, H., K. Kailasapathy, and M. Phillips. 2006. Evaluation of alginate-pectin capsules in Cheddar cheese as a food carrier for the delivery of folic acid. LWT Food Sci. Technol. 39:146-151. https:// doi.org/10.1016/j.lwt.2004.12.015.

Månsson, H. L. 2008. Fatty acids in bovine milk fat. Food Nutr. Res. 52:1821 https://doi.org/10.3402/fnr.v52i0.1821

Marshall, R. J. 1990. Composition, structure, rheological properties, and sensory texture of processed cheese analogues. J. Sci. Food Agric. 50:237-252. https://doi.org/10.1002/jsfa.2740500211.

Martley, F. G., and V. L. Crow. 1996. Open texture in cheese: the contributions of gas production by microorganisms and cheese manufacturing practices. J. Dairy Res. 63:489-507. https://doi.org/10 $1017 /$ S0022029900032015.

McAuliffe, L. N., K. N. Kilcawley, J. J. Sheehan, and P. L. H. McSweeney. 2016. Manufacture and incorporation of liposome-entrapped ethylenediaminetetraacetic acid into model miniature Gouda-type cheese and subsequent effect on starter viability, $\mathrm{pH}$, and moisture content. J. Food Sci. 81:C2708-C2717. https://doi.org/10.1111/ 1750-3841.13519.

McClements, D. J., E. A. Decker, Y. Park, and J. Weiss. 2009. Structural design principles for delivery of bioactive components in nutraceuticals and functional foods. Crit. Rev. Food Sci. Nutr. 49:577-606. https://doi.org/10.1080/10408390902841529.

McMahon, D. J., R. L. Fife, and C. J. Oberg. 1999. Water partitioning in Mozzarella cheese and its relationship to cheese meltability. J. Dairy Sci. 82:1361-1369. https://doi.org/10.3168/jds.S0022 -0302(99)75361-0.

McMahon, D. J., B. Paulson, and C. J. Oberg. 2005. Influence of calcium, $\mathrm{pH}$, and moisture on protein matrix structure and functionality in direct-acidified nonfat Mozzarella cheese. J. Dairy Sci. 88:3754-3763. https://doi.org/10.3168/jds.S0022-0302(05)73061 -7 .

McSweeney, P. L. H. 2004. Biochemistry of cheese ripening. Int. J. Dairy Technol. 57:127-144. https://doi.org/10.1111/j.1471-0307 .2004.00147.x.

Mellema, M., P. Walstra, J. H. J. Van Opheusden, and T. Van Vliet. 2002. Effects of structural rearrangements on the rheology of rennet-induced casein particle gels. Adv. Colloid Interface Sci. 98:2550. https://doi.org/10.1016/S0001-8686(01)00089-6.

Michalski, M.-C., B. Camier, V. Briard, N. Leconte, J.-Y. Gassi, H. Goudédranche, F. Michel, and J. Fauquant. 2004. The size of native milk fat globules affects physico-chemical and functional properties of Emmental cheese. Lait 84:343-358. https://doi.org/ 10.1051/lait:2004012.

Michalski, M.-C., B. Camier, J.-Y. Gassi, V. Briard-Bion, N. Leconte, M.-H. Famelart, and C. Lopez. 2007. Functionality of smaller vs control native milk fat globules in Emmental cheeses manufactured with adapted technologies. Food Res. Int. 40:191-202. https://doi .org/10.1016/j.foodres.2006.09.011.

Michalski, M. C., R. Cariou, F. Michel, and C. Garnier. 2002. Native vs. damaged milk fat globules: Membrane properties affect the viscoelasticity of milk gels. J. Dairy Sci. 85:2451-2461. https://doi .org/10.3168/jds.S0022-0302(02)74327-0.
Michalski, M.-C., J.-Y. Gassi, M.-H. Famelart, N. Leconte, B. Camier, F. Michel, and V. Briard. 2003. The size of native milk fat globules affects physico-chemical and sensory properties of Camembert cheese. Lait 83:131-143. https://doi.org/10.1051/lait:2003003.

Møller, K. K., F. P. Rattray, W. L. P. Bredie, E. Høier, and Y. Ardö. 2013. Physicochemical and sensory characterization of Cheddar cheese with variable $\mathrm{NaCl}$ levels and equal moisture content. J. Dairy Sci. 96:1953-1971. https://doi.org/10.3168/jds.2012-5524.

Monteiro, R. R., D. Q. Tavares, P. S. Kindstedt, and M. L. Gigante 2009. Effect of $\mathrm{pH}$ on microstructure and characteristics of cream cheese. J. Food Sci. 74:C112-C117. https://doi.org/10.1111/j.1750 $-3841.2008 .01037 . x$.

Moynihan, A. C., S. Govindasamy-Lucey, J. J. Jaeggi, M. E. Johnson, J. A. Lucey, and P. L. H. McSweeney. 2014. Effect of camel chymosin on the texture, functionality, and sensory properties of low-moisture, part-skim Mozzarella cheese. J. Dairy Sci. 97:85-96. https://doi.org/10.3168/jds.2013-7081.

O'Mahony, J. A., J. A. Lucey, and P. L. H. McSweeney. 2005. Chymosin-mediated proteolysis, calcium solubilization, and texture development during the ripening of Cheddar cheese. J. Dairy Sci. 88:3101-3114. https://doi.org/10.3168/jds.S0022-0302(05)72992 $-1$.

O’Mahony, J. A., P. L. H. McSweeney, and J. A. Lucey. 2006. A model system for studying the effects of colloidal calcium phosphate concentration on the rheological properties of Cheddar cheese. J. Dairy Sci. 89:892-904. https://doi.org/10.3168/jds.S0022-0302(06)72154 $-3$.

OECD/FAO. 2016. OECD-FAO Agricultural Outlook 2016-2025. OECD Publishing, Paris, France. https://doi.org/10.1787/agr _outlook-2016-en.

Oliver, L., L. Berndsen, G. A. van Aken, and E. Scholten. 2015. Influence of droplet clustering on the rheological properties of emulsion-filled gels. Food Hydrocoll. 50:74-83. https://doi.org/10 .1016/j.foodhyd.2015.04.001.

Ong, L., R. R. Dagastine, M. A. E. Auty, S. E. Kentish, and S. L. Gras. 2011a. Coagulation temperature affects the microstructure and composition of full fat Cheddar cheese. Dairy Sci. Technol. 91:739 https://doi.org/10.1007/s13594-011-0033-6.

Ong, L., R. R. Dagastine, S. E. Kentish, and S. L. Gras. 2011b. Microstructure of milk gel and cheese curd observed using cryo scanning electron microscopy and confocal microscopy. LWT Food Sci. Technol. 44:1291-1302. https://doi.org/10.1016/j.lwt.2010.12.026.

Ong, L., R. R. Dagastine, S. E. Kentish, and S. L. Gras. 2012. The effect of $\mathrm{pH}$ at renneting on the microstructure, composition and texture of Cheddar cheese. Food Res. Int. 48:119-130. https://doi .org/10.1016/j.foodres.2012.02.020

Parada, J., and J. M. Aguilera. 2007. Food microstructure affects the bioavailability of several nutrients. J. Food Sci. 72:R21-R32. https://doi.org/10.1111/j.1750-3841.2007.00274.x.

Pastorino, A. J., C. L. Hansen, and D. J. McMahon. 2003a. Effect of $\mathrm{pH}$ on the chemical composition and structure-function relationships of Cheddar cheese. J. Dairy Sci. 86:2751-2760. https://doi .org/10.3168/jds.S0022-0302(03)73871-5.

Pastorino, A. J., C. L. Hansen, and D. J. McMahon. 2003b. Effect of salt on structure-function relationships of cheese. J. Dairy Sci 86:60-69. https://doi.org/10.3168/jds.S0022-0302(03)73584-X.

Pastorino, A. J., N. P. Ricks, C. L. Hansen, and D. J. McMahon. 2003c. Effect of calcium and water injection on structure-function relationships of cheese. J. Dairy Sci. 86:105-113. https://doi.org/ 10.3168/jds.S0022-0302(03)73589-9.

Paulson, B. M., D. J. McMahon, and C. J. Oberg. 1998. Influence of sodium chloride on appearance, functionality, and protein arrangements in nonfat Mozzarella cheese. J. Dairy Sci. 81:2053-2064. https://doi.org/10.3168/jds.S0022-0302(98)75780-7.

Petukhov, M., G. Rychkov, L. Firsov, and L. Serrano. 2004. H-bonding in protein hydration revisited. Protein Sci. 13:2120-2129. https:// doi.org/10.1110/ps.04748404.

Poole, L. B. 2015. The basics of thiols and cysteines in redox biology and chemistry. Free Radic. Biol. Med. 80:148-157. https://doi .org/10.1016/j.freeradbiomed.2014.11.013. 
Rashidinejad, A., E. J. Birch, and D. W. Everett. 2016. A novel functional full-fat hard cheese containing liposomal nanoencapsulated green tea catechins: Manufacture and recovery following simulated digestion. Food Funct. 7:3283-3294. https://doi.org/10.1039/ c6fo00354k.

Remillard, N., and M. Britten. 2011. Quantitative determination of micellar calcium in milk and cheese using acid-base titration. Milchwissenschaft 66:137-140.

Richoux, R., L. Aubert, G. Roset, and J.-R. Kerjean. 2009. Impact of the proteolysis due to lactobacilli on the stretchability of Swisstype cheese. Dairy Sci. Technol. 89:31-41. https://doi.org/10 .1051 dst:2008030.

Rogers, N. R., M. A. Drake, C. R. Daubert, D. J. McMahon, T. K. Bletsch, and E. A. Foegeding. 2009. The effect of aging on lowfat, reduced-fat, and full-fat Cheddar cheese texture. J. Dairy Sci. 92:4756-4772. https://doi.org/10.3168/jds.2009-2156.

Rogers, N. R., D. J. McMahon, C. R. Daubert, T. K. Berry, and E. A. Foegeding. 2010. Rheological properties and microstructure of Cheddar cheese made with different fat contents. J. Dairy Sci. 93:4565-4576. https://doi.org/10.3168/jds.2010-3494.

Sadat-Mekmene, L., R. Richoux, L. Aubert-Frogerais, M. N. Madec, C. Corre, M. Piot, J. Jardin, S. le Feunteun, S. Lortal, and V. Gagnaire. 2013. Lactobacillus helveticus as a tool to change proteolysis and functionality in Swiss-type cheeses. J. Dairy Sci. 96:1455-1470. https://doi.org/10.3168/jds.2012-6179.

Sala, G., F. van de Velde, M. A. Cohen Stuart, and G. A. van Aken. 2007. Oil droplet release from emulsion-filled gels in relation to sensory perception. Food Hydrocoll. 21:977-985. https://doi.org/ 10.1016/j.foodhyd.2006.08.009.

Salaün, F., B. Mietton, and F. Gaucheron. 2005. Buffering capacity of dairy products. Int. Dairy J. 15:95-109. https://doi.org/10.1016/ j.idairyj.2004.06.007.

Sharp, M. D., D. J. McMahon, and J. R. Broadbent. 2008. Comparative evaluation of yogurt and low-fat Cheddar cheese as delivery media for probiotic Lactobacillus casei. J. Food Sci. 73:M375M377. https://doi.org/10.1111/j.1750-3841.2008.00882.x.

Sheehan, J. J. 2013. Milk quality and cheese diversification. Ir. J. Agric. Food Res. 52:243-253.

Sheehan, J. J., and T. P. Guinee. 2004. Effect of pH and calcium level on the biochemical, textural and functional properties of reducedfat Mozzarella cheese. Int. Dairy J. 14:161-172. https://doi.org/10 .1016/S0958-6946(03)00167-5.

Sheehan, J. J., J. C. Oliveira, A. L. Kelly, and P. L. H. McSweeney. 2007. Effect of cook temperature on primary proteolysis and predicted residual chymosin activity of a semi-hard cheese manufactured using thermophilic cultures. Int. Dairy J. 17:826-834. https://doi.org/10.1016/j.idairyj.2006.08.012.

Shima, H., and M. Tanimoto. 2016. Effect of milk fat content on the viscoelasticity of Mozzarella-type cheese curds. Eur. Food Res. Technol. 242:157-162. https://doi.org/10.1007/s00217-015-2525-8.

Singh, H., A. Ye, and M. J. Ferrua. 2015. Aspects of food structures in the digestive tract. Curr. Opin. Food Sci. 3:85-93. https://doi.org/ 10.1016/j.cofs.2015.06.007.

Smith, J. R., S. J. Vogt, J. D. Seymour, A. J. Carr, and S. L. Codd. 2017. Probing water migration in Mozzarella cheese during mat- uration and heating utilizing magnetic resonance techniques. J. Food Eng. 198:1-6. https://doi.org/10.1016/j.jfoodeng.2016.11 .010 .

Soodam, K., L. Ong, I. B. Powell, S. E. Kentish, and S. L. Gras. 2015. Effect of rennet on the composition, proteolysis and microstructure of reduced-fat Cheddar cheese during ripening. Dairy Sci. Technol. 95:665-686. https://doi.org/10.1007/s13594-015-0250-5.

Sousa, M. J., Y. Ardö, and P. L. H. McSweeney. 2001. Advances in the study of proteolysis during cheese ripening. Int. Dairy J. 11:327345. https://doi.org/10.1016/S0958-6946(01)00062-0.

Stieger, M., and F. van de Velde. 2013. Microstructure, texture and oral processing: New ways to reduce sugar and salt in foods. Curr. Opin. Colloid Interface Sci. 18:334-348. https://doi.org/10.1016/ j.cocis.2013.04.007.

Taneya, S., T. Izutsu, T. Kimura, and T. Shioya. 1992. Structure and rheology of string cheese. Food Struct. 11:7.

Taylor, A. J. 2002. Release and transport of flavors in vivo: Physicochemical, physiological, and perceptual considerations. Compr. Rev. Food Sci. Food Saf. 1:45-57. https://doi.org/10.1111/j.1541 -4337.2002.tb00006.x.

Thionnet, O., P. Havea, G. Gillies, M. Lad, and M. Golding. 2017. Influence of the volume fraction, size and surface coating of hard spheres on the microstructure and rheological properties of model Mozzarella cheese. Food Biophys. 12:33-44. https://doi.org/10 .1007/s11483-016-9460-5.

van Vliet, T., G. A. van Aken, H. H. J. de Jongh, and R. J. Hamer. 2009. Colloidal aspects of texture perception. Adv. Colloid Interface Sci. 150:27-40. https://doi.org/10.1016/j.cis.2009.04.002.

Visschers, R. W., M. A. Jacobs, J. Frasnelli, T. Hummel, M. Burgering, and A. E. M. Boelrijk. 2006. Cross-modality of texture and aroma perception is independent of orthonasal or retronasal stimulation. J. Agric. Food Chem. 54:5509-5515. https://doi.org/ 10.1021/jf060533c.

Vogt, S. J., J. R. Smith, J. D. Seymour, A. J. Carr, M. D. Golding, and S. L. Codd. 2015. Assessment of the changes in the structure and component mobility of Mozzarella and Cheddar cheese during heating. J. Food Eng. 150:35-43. https://doi.org/10.1016/ j.jfoodeng.2014.10.026.

White, S. R., J. R. Broadbent, C. J. Oberg, and D. J. McMahon. 2003. Effect of Lactobacillus helveticus and Propionibacterium freudenrichii ssp. shermanii combinations on propensity for split defect in Swiss cheese. J. Dairy Sci. 86:719-727. https://doi.org/10.3168/jds .S0022-0302(03)73652-2.

Wium, H., P. S. Pedersen, and K. B. Qvist. 2003. Effect of coagulation conditions on the microstructure and the large deformation properties of fat-free Feta cheese made from ultrafiltered milk. Food Hydrocoll. 17:287-296. https://doi.org/10.1016/S0268 -005X(02)00079-6.

Zamora, A., A. J. Trujillo, E. Armaforte, D. S. Waldron, and A. L. Kelly. 2012. Effect of fat content and homogenization under conventional or ultra-high-pressure conditions on interactions between proteins in rennet curds. J. Dairy Sci. 95:4796-4803. https://doi .org/10.3168/jds.2012-5351. 